\title{
Abiotic and biotic factors used to assess decline risk in red pine [Pinus resinosa Ait.] plantations
}

\author{
by J.A. McLaughlin ${ }^{1,2}$, T. Hsiang ${ }^{3}$, G. Halicki Hayden ${ }^{1}$ and S. Greifenhagen ${ }^{1}$
}

\begin{abstract}
This study was conducted to assess causes of unprecedented rates of mortality in maturing, commercial-sized red pine (Pinus resinosa Ait.) plantations in southern Ontario, Canada. Concentrated and diffuse mortality as well as windthrow of living trees were observed in many plantations, while others seemed disease-free. Nine sites exhibiting recent mortality (diseased) plus three not exhibiting disease (healthy) were selected. In sample plots at each site, abiotic site factors, host characteristics, and insect pests and fungal pathogens were assessed. Tree mortality was attributed to Armillaria root disease, annosus root rot, black pineleaf scale, drought, and iron deficiency. The single abiotic factor that distinguished healthy sites from diseased sites was $\mathrm{C}$ soil horizon $\mathrm{pH}$, which averaged 8.35 on diseased sites compared to 6.55 on healthy sites. Rooting was also deeper on healthy sites than on diseased sites. We suggest that an alkaline $\mathrm{C}$ horizon may result in shallower rooting and greater susceptibility to drought stress, rendering trees less resistant to root disease pathogens and insect pests. The $\mathrm{pH}$ of the $\mathrm{C}$ horizon and the depth of the $\mathrm{A}$ and $\mathrm{B}$ horizons may be useful as indicators of the likelihood of red pine mortality and to guide the choice of management objectives for plantations.
\end{abstract}

Key words: red pine mortality, root disease, calcareous soil, rooting depth, Armillaria

\section{RÉSUMÉ}

Cette étude a été entreprise afin d'identifier les causes de mortalité à des taux sans précédents relevés dans des plantations industrielles à maturité de pin rouge (Pinus resinosa Ait.) dans le sud de l'Ontario au Canada. La mortalité concentrée et diffuse ainsi que le renversement d’arbres vivants ont été observés dans plusieurs plantations, tandis que d’autres semblaient être exemptes de maladie. Neuf stations affichant une mortalité récente (malades) et trois autres sans signe de maladie (saines) ont été sélectionnées. Dans les parcelles-échantillons de chacune des stations, les facteurs abiotiques de la station, les caractéristiques des végétaux et les insectes ravageurs ainsi que les pathogènes fongiques ont été relevés. La mortalité des arbres a été reliée au pourridié-agaric, à la maladie du rond, aux cochenilles des aiguilles du pin, à la sécheresse et à la carence en fer. Le seul facteur abiotique démarquant les stations saines des stations malades était le pH de l'horizon $\mathrm{C}$ qui atteignait une moyenne de 8,35 sur les stations malades comparativement à 6,55 sur les stations saines. L’enracinement était également plus profond dans les stations saines comparativement aux stations malades. Nous croyons qu'un horizon $\mathrm{C}$ alcalin pourrait entraîner un enracinement plus superficiel et une plus grande susceptibilité au stress hydrique, faisant en sorte que les arbres sont moins résistants aux pathogènes racinaires et aux insectes ravageurs. Le $\mathrm{pH}$ de l'horizon $\mathrm{C}$ et la profondeur des horizons $\mathrm{A}$ et $\mathrm{B}$ pourraient être des indicateurs utiles de lestimation de la mortalité du pin rouge et pour orienter le choix d’objectifs d’aménagement des plantations.

Mots clés : mortalité du pin rouge, maladie racinaire, sol calcaire, profondeur d’enracinement, Armillaria

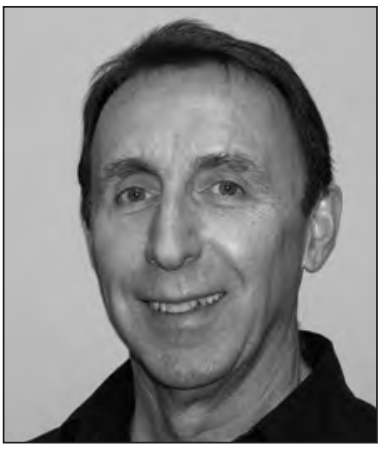

J.A. McLaughlin

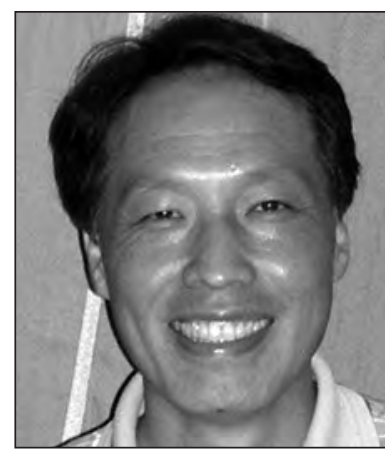

T. Hsiang

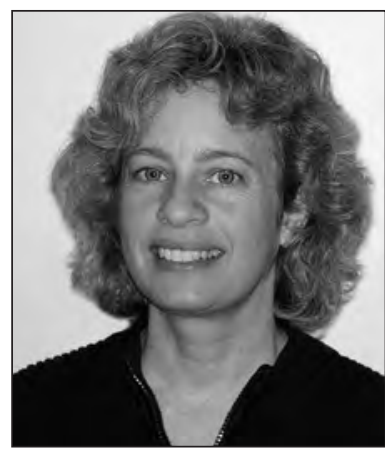

G. Halicki Hayden

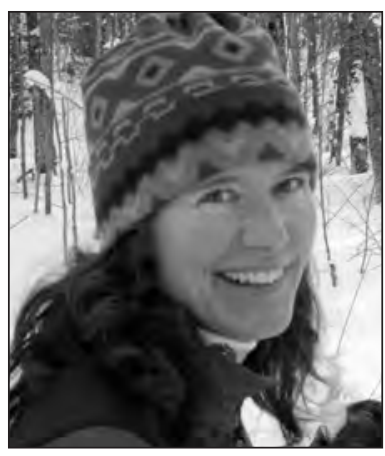

S. Greifenhagen

${ }^{1}$ Ontario Forest Research Institute, 1235 Queen St. E., Sault Ste. Marie, Ontario P6A 2E5.

${ }^{2}$ Corresponding author. E-mail: john.mclaughlin@ontario.ca

${ }^{3}$ School of Environmental Sciences, University of Guelph, Guelph, Ontario N1G 2W1. 


\section{Introduction}

Red pine (Pinus resinosa Ait.) is a shade-intolerant conifer that is among the most extensively planted species in eastern Canada and the northern United States (Rudolf 1990). Red pine is valued because of its ability to grow on sites too poor for agriculture, the many uses for its timber (e.g., as sawlogs, utility poles, and preservative-treated landscape timbers), its suitability for plantation silviculture, economic returns to landowners through thinnings over the rotation period, and its relatively greater resistance to pests (Hosie 1979, OMNR 1999). Red pine plantations are even-aged and evenly spaced, with co-dominant crown structure. In addition, because of red pine's relatively low genetic diversity (Mosseler et al. 1992), significant differences in individual tree size within a stand result mostly from differences in how the seedlings were planted, or microsite (e.g., soil characteristics), or subsequent mechanical damage, or animal browsing. Trees that are negatively affected at any stage of growth may fall behind their cohorts in growth rate and crown position, and thus decline in fitness. Ultimately, such trees may be more susceptible to disease and insect attack (Schoeneweiss 1975).

In some parts of southern and central Ontario, Canada, unprecedented rates of mortality in maturing, commercialsized red pine are challenging forest managers who attempt to adhere to traditional management strategies and silvicultural practices. Landowners are losing decades of investment in thinning and tending through sudden mortality. In addition to the financial impacts of timber losses wood supply is also affected and broader forest management objectives (e.g., stand conversion to a mixed forest as the red pine stand is gradually opened by thinnings, and recreational values) can be adversely affected (B. Hutchison, Simcoe County Forest Technician, personal communication).

The mortality has been observed in several forms: renewed and rapid expansion of old mortality centres
(McLaughlin 2001a), appearance of new pockets of tree mortality (often immediately after a thinning), single-tree mortality, and windthrow of living trees with advanced root decay. Preliminary and anecdotal reports have associated the mortality in southern Ontario, New York State and elsewhere with a variety of biotic and abiotic factors such as drought (OMNR and NRCan 2007), poor soil drainage (Stone et al. 1954), nutrient deficiency (Stone 1953, Ellis and Whitney 1975), fungal root pathogens (Whitney 1988; McLaughlin 2001a, b), and insect pests (Czerwinski et al. 1998).

The primary aim of this study was to identify biotic and abiotic factors associated with decline and mortality of red pine plantations in southern Ontario, and in particular to identify any underlying tree or site characteristics that could help to explain the presence or absence of disease and mortality on all study sites, regardless of the biotic or abiotic factors or agents that were most evident. Further aims were to devise a risk assessment method to help resource managers identify sites and plantations vulnerable to excessive mortality and to recommend management options to mitigate mortality losses.

\section{Methods}

Comparisons between healthy and diseased conditions were made at three levels: between sites with healthy trees and those with mortality; between plots located in healthy or diseased parts of stands with diseased trees; and between healthy and diseased/dead trees within plots with diseased trees.

\section{Selecting study sites}

Twelve study sites representing red pine plantations between 28 and 77 years old across southern Ontario were selected for detailed study (Fig. 1, Table 1). At nine of the sites spreading mortality pockets were evident in the red pine (diseased sites), and at three sites the trees were apparently healthy with no

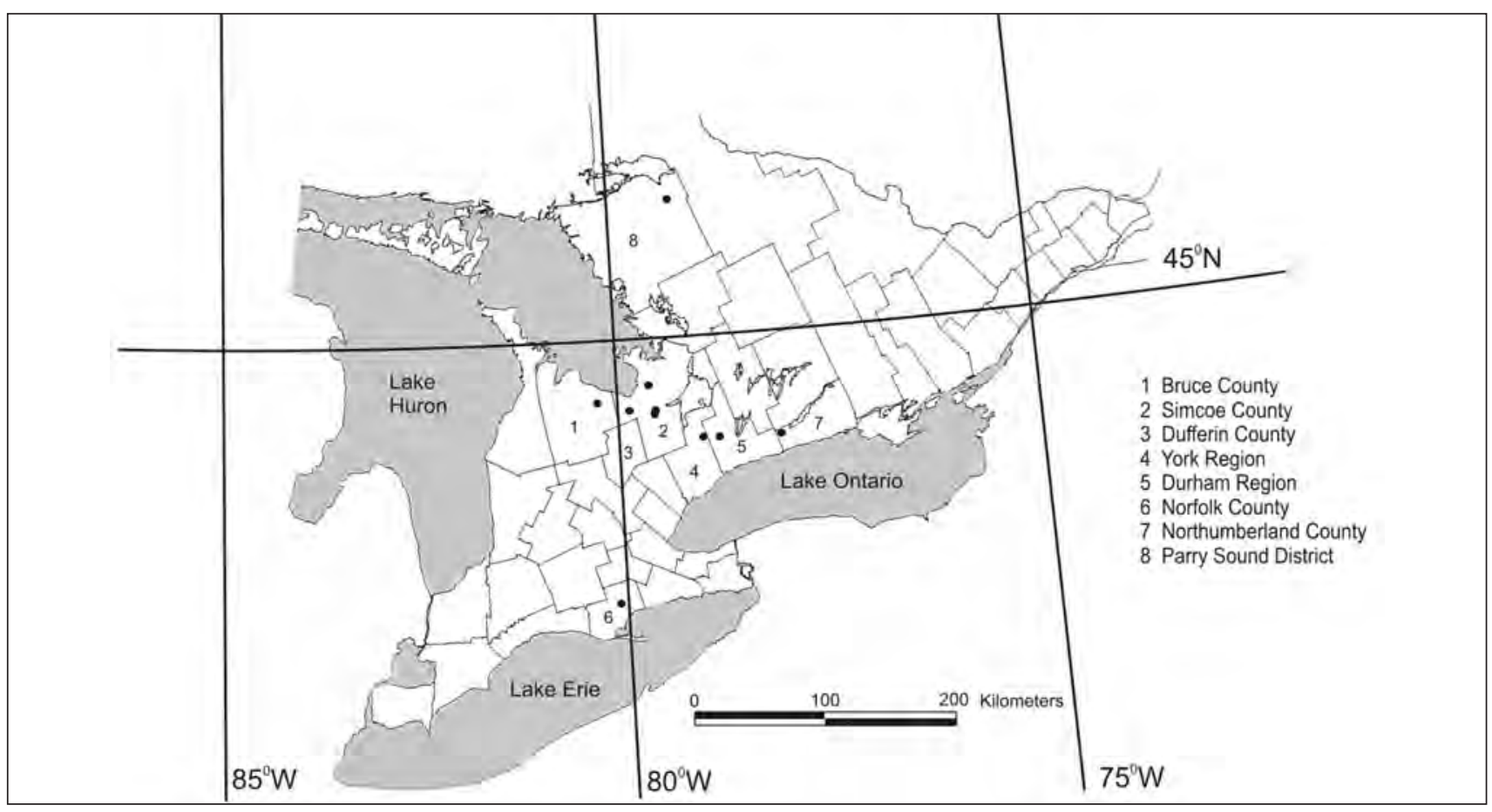

Fig. 1. Location of red pine mortality study sites in southern Ontario. 
Table 1. Sites in southern Ontario, Canada, included in the red pine mortality study

\begin{tabular}{|c|c|c|c|c|c|}
\hline \multirow[b]{2}{*}{ County } & \multicolumn{2}{|c|}{ Location } & \multirow[b]{2}{*}{ Soil type ${ }^{c}$} & \multirow{2}{*}{$\begin{array}{l}\text { Soil parent } \\
\text { material }\end{array}$} & \multirow[b]{2}{*}{ Tree age } \\
\hline & Primary Site (\# of plots) ${ }^{\mathrm{a}}$ & Auxiliary Site ${ }^{b}$ & & & \\
\hline \multirow[t]{16}{*}{ Simcoe } & Baxter 243b-N (1) & - & GBP, Tioga $1 S^{\mathrm{d}}$ & calcareous & 67 \\
\hline & Baxter 243b-S (1) & - & GBP, Tioga IS & calcareous & 67 \\
\hline & Baxter 249b (2) & - & GBP, Tioga IS & calcareous & 64 \\
\hline & Phelpston 162e (1) & - & P, Wyevale grav/L & non-calcareous & 59 \\
\hline & Phelpston 165b (2) & - & $\mathrm{P}$, Wyevale grav/L & non-calcareous & 62 \\
\hline & - & Hickling 211a & GBP, Vasey sL & mixed & 57 \\
\hline & - & Hendrie Main 202a & GBP, Tioga S & calcareous & 70 \\
\hline & - & Orrock Cr. S. 179a & GBP, Tioga S & calcareous & 67 \\
\hline & - & Wildman Main 17a & GBP, Tioga $S$ & calcareous & 64 \\
\hline & - & Drury Main $151 \mathrm{e}$ & GBP, Tioga S/Vasey sL & mixed & 62 \\
\hline & - & Vasey $54 \mathrm{a}$ & GBP, Tioga S/Vasey sL & mixed & 60 \\
\hline & - & Douglas 98a & GBP, Tioga $S$ & calcareous & 58 \\
\hline & - & Barker $219 \mathrm{e}$ & GBP, Tioga S & calcareous & 65 \\
\hline & - & SCAC PSP & BF, Sargent sL & calcareous & $\sim 57$ \\
\hline & - & Waverley 83a PSP $A^{\mathrm{e}}$ & GBP, Tioga S/Vasey sL & mixed & 72 \\
\hline & - & Waverley 83a PSP M ${ }^{\mathrm{e}}$ & GBP, Tioga S/Vasey sL & mixed & 72 \\
\hline Dufferin & Randwick 1 (2) & - & GBP, Tioga S & calcareous & 64 \\
\hline Bruce & Grey-Sauble 89/11 (2) & - & GBP, Harriston SiL & calcareous & 38 \\
\hline Northumberland & Ganaraska 7b (2) & - & GBP, Pontypool S & calcareous & 55 \\
\hline \multirow[t]{3}{*}{ York Region } & North 30b (2) & - & GBP, Pontypool S & calcareous & 67 \\
\hline & - & Eldred King 57 & GBP, Pontypool S & calcareous & - \\
\hline & - & Patterson $69 \mathrm{a}$ & GBP, Brighton sL & calcareous & 77 \\
\hline Durham Region & Brookdale 8a (2) & - & GBP, Pontypool S & calcareous & 57 \\
\hline \multirow[t]{4}{*}{ Norfolk } & Miller Lumber site (2) & - & GBP, Brady fS/sL & calcareous & $\sim 75$ \\
\hline & - & St. Williams 490 & - & - & - \\
\hline & - & Turkey Point 822 & - & - & - \\
\hline & - & Turkey Point 845 & - & - & - \\
\hline $\begin{array}{l}\text { Parry Sound } \\
\text { District }\end{array}$ & $\begin{array}{l}\text { Gurd Tree Improvement } \\
\text { Area } \operatorname{Pr} 18(2)\end{array}$ & - & grav/sL & non-calcareous & 28 \\
\hline
\end{tabular}

aplots where trenches were dug and intensive soil and rooting sampling was conducted

badditional sites selected for $\mathrm{C}$ horizon $\mathrm{pH}$ sampling

${ }^{\mathrm{c}}$ Great Group (GBP = Grey-Brown Podzolic; P = Podzolic; BF = Brown Forest) and Series according to the Canadian System of Soil Classification (Agriculture Canada Expert Committee on Soil Survey 1987)

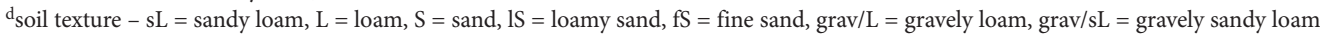

${ }^{\mathrm{e}} \mathrm{A}=$ asymptomatic; $\mathrm{M}=$ mortality observed

mortality pockets (healthy sites). All but one site, the Gurd Tree Improvement Area, were located south of the Pre-Cambrian Shield. All sites had been thinned at least once. Candidate sites were visited prior to selection and putative causal factors were identified whenever possible. Final site selection was based on maximizing geographic and putative causal variation, with a focus on sites with root disease, which are common in southern Ontario (Whitney 1988; McLaughlin 2001a, b). The field studies were conducted in 2004.

\section{Selecting sample plots}

At the nine diseased sites, two $400-\mathrm{m}^{2}$ circular plots were established in each plantation. One plot was established where it would include at least one recently dead or dying tree (mortality plot), and the second plot was located where trees appeared healthy (asymptomatic plot), without any mortality nearby. At each of the three healthy sites, a $400-\mathrm{m}^{2}$ circular plot was located to include trees that represented the overall health of the plantation. In total, 18 plots were established at nine disease sites and three plots were established at three healthy sites. Following analysis of data from these plots, the $\mathrm{pH}$ of the $\mathrm{C}$ soil horizon was sampled on 16 additional sites, nine where trees appeared to be healthy and seven that exhibited disease.

\section{Identifying causal factors}

In summer 2004 each sample plot was examined for symptoms and signs of abiotic and biotic factors that have been reported as causing red pine mortality, including moisture deficit, nutrient deficiency, root disease, and insect pests. Where root disease was suspected, the root collar area of dying or dead trees was examined for the presence of fruiting 
bodies of Heterobasidion annosum (Fr.) Bref., the cause of annosus root rot, and the rhizomorphs or mycelial fans associated with Armillaria root disease. Infected root material was collected to isolate and identify the fungal pathogens. Armillaria isolates were identified to species using the protocol developed by McLaughlin and Hsiang (2010), and H. annosum infection was confirmed by observing the asexual stage, Spiniger meineckellus (Olson) Stalpers, on host tissue incubated in a moist chamber based on the method of Worrall and Harrington (1992). Bark beetles and scale insects occurring on trees in the plots were collected for later identification.

\section{Assessing tree characteristics}

Data were collected to test the hypothesis that the trees that died were the smaller, less vigorous ones. Tree diameter (DBH) and height were measured on all trees in each plot, except at the Grey-Sauble site where height was measured on 10 and 16 randomly selected trees in the asymptomatic and mortality plots, respectively. In addition, growth ring measurements and analyses were conducted on cross-sectional discs cut at breast height $(1.3 \mathrm{~m})$ from two to four living and dead trees from the plot centre, and on radial cores extracted by increment borer at breast height on the north, southeast, and southwest sides of several trees in each plot. At the Baxter $249 \mathrm{~b}$ plantation additional cookies were cut from recently dead trees from outside the mortality plot. This site was selected for more intensive study because mortality was distributed throughout much of the plantation.

Tree discs and increment cores were sealed in plastic bags to prevent drying and shrinkage, and stored frozen until processed. The surface of one side of each cookie was sanded smooth and then scanned for analysis with the WinDendro Image Analysis System (Regent Instruments Inc., Sainte-Foy, Québec). The growth ring widths were measured and recorded along four radial axes. Annual growth rings on increment cores were also measured with a tree ring increment measuring (TRIM) system (MacIvor et al. 1985). For both disc and increment core samples mean annual growth ring widths were calculated and converted to basal area increment (BAI) using the formula: $\mathrm{BAI}_{\mathrm{t}}=\Pi\left(\mathrm{r}_{\mathrm{t}}^{2} \mathrm{r}_{\mathrm{t}-1}{ }^{2}\right)$, where $\mathrm{r}=$ tree radius and $\mathrm{t}=$ year of ring formation (Duchesne $e t$ al. 2003).

The BAI of healthy trees or trees in asymptomatic plots (depending on the comparison being made) was standardized for comparing with dead trees or trees in mortality plots from different sites. Standardization is commonly used in dendrochronology studies to remove unwanted variation in growth ring size attributable to differences in tree age and species. It is achieved by transforming non-stationary ring widths into a new series of stationary, relative values with a defined mean of 1.0 and homogenous variance, producing a smooth growth trend line (expected growth) against which the growth of the tree(s) of interest (actual growth) can be compared (Cook et al. 1989, Duchesne et al. 2003). The annual mean ring width of living trees was the expected growth to which the actual growth of the trees that had died was compared.

\section{Sampling soil, tree roots, and mycorrhizae}

Soil sampling and tree root measurements followed a protocol derived from Brown and Lacate (1961). First, a trench $2 \mathrm{~m}$ deep, about $2 \mathrm{~m}$ wide and up to $20 \mathrm{~m}$ long (Fig. 2) was dug

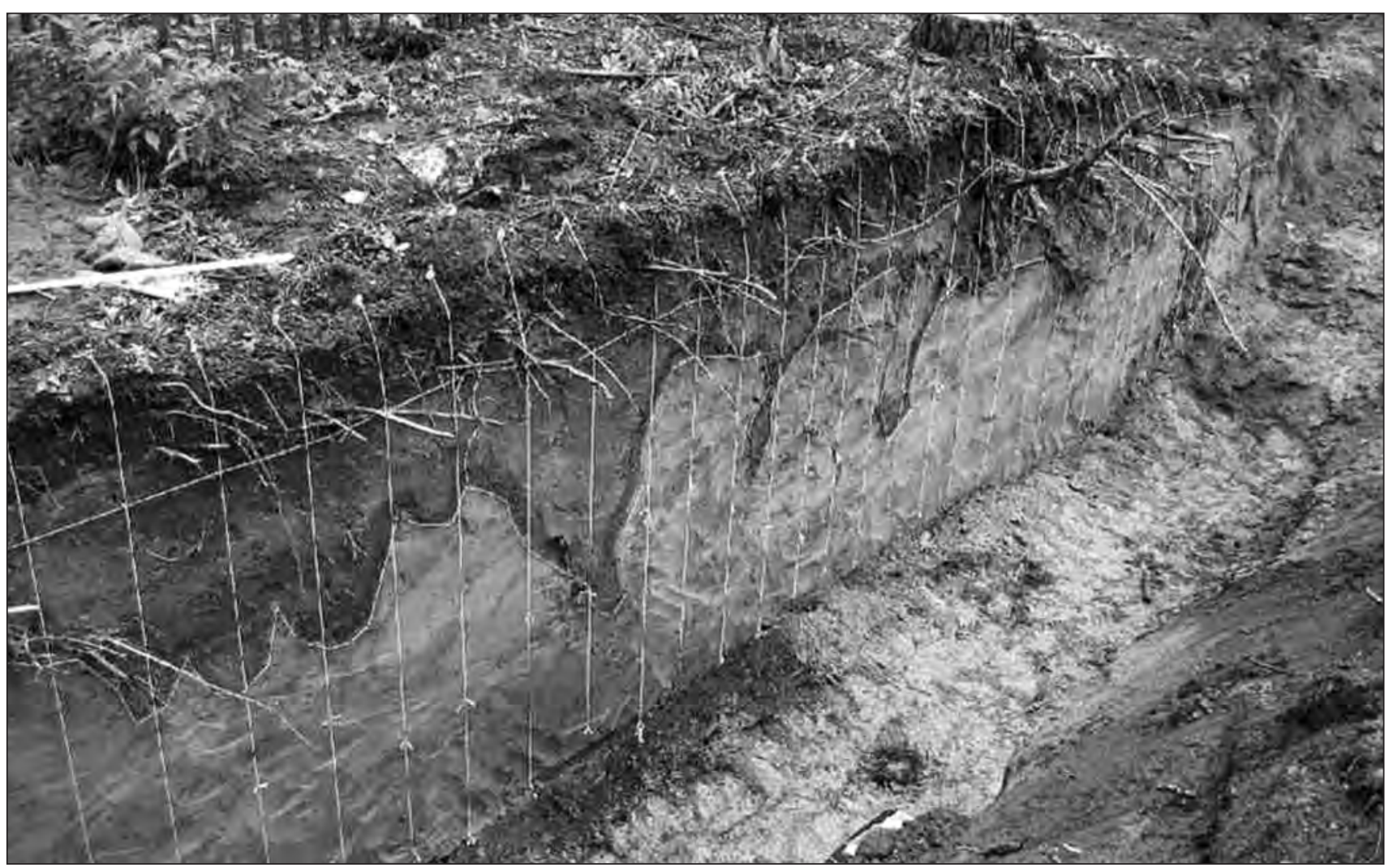

Fig. 2. Two-m-deep trench with sampling grid. 
beside two to four trees in the centre of each plot. Then a 25 $\times 25 \mathrm{~cm}$ grid was laid out on the trench face below the stumps using weighted strings suspended $25 \mathrm{~cm}$ apart down the trench face. Horizontal grid lines were marked on the trench face at $25-\mathrm{cm}$ intervals. Next, the depth of A, B and C soil horizons were measured in each vertical grid column. Then tree roots were mapped over the trench face by recording their presence or absence in each grid squares. Finally, soil samples were collected from each soil horizon below each tree.

\section{Soil texture, $\mathrm{pH}$, and bulk density}

Soil samples (up to $500 \mathrm{ml}$ ) were collected at each horizon, at three points under each tree - directly under the tree, and at $1 \mathrm{~m}$ on each side-for texture and $\mathrm{pH}$ analyses. Bulk density samples were collected with a $100-\mathrm{ml}$ cylinder pressed into the trench wall. When samples for adjacent trees overlapped, a single sample was used for both trees.

Soil texture (i.e., particle size) was measured by the Bouyoucos Hydrometer method (Bouyoucos 1962) according to the standard operating procedures of the Ontario Forest Research Institute's laboratory services (OFRILS) in Sault Ste. Marie, Ontario. Soil pH was determined by two methods. The $\mathrm{pH}$ of soil samples from principal study sites sampled from trench walls was determined by the 1:2 soil:water ratio method (standard operating procedure by OFRILS). Samples from additional sites were processed using the saturated paste method (standard operating procedure of the Soil and Nutrient Laboratory Lab Services (UGLS), University of Guelph, Guelph, Ontario). Soil bulk density was determined using the method by Kalra and Maynard (1991).

\section{Soil nutrients}

Soil samples for nutrient analysis were collected in each horizon, at three locations under the trees beside the trench, as described above. The samples were stored in coolers during the day of collection and then shipped on ice to OFRILS, where they were held at $4^{\circ} \mathrm{C}$.

\section{Mycorrhizal colonization}

For mycorrhizal sampling at healthy and diseased sites, plots were divided into four quadrants and one living tree was selected from each quadrant. Four blocks of soil measuring approximately $20 \times 20 \times 20 \mathrm{~cm}$ were dug out of the surface soil layer $1 \mathrm{~m}$ in each cardinal direction from the base of the tree. The soil blocks were taken to the lab where they were soaked in water overnight and the roots carefully separated from soil and other debris. For each sample, up to $120 \mathrm{~cm}$ of roots less than $1 \mathrm{~mm}$ in diameter were assessed (Richter and Bruhn 1993). The roots were then viewed under a dissecting microscope and the number of mycorrhizal tips per $\mathrm{cm}$ of fine root recorded.

\section{Sampling foliar nutrient content}

Red pine foliage was collected at seven sites (Baxter 243b-N, Baxter 243b-S, Phelpston 162e, Baxter 249b, Phelpston 165b, Grey-Sauble 89/11, and Ganaraska 7b) in early November, 2005 to test the hypothesis that the trees that died were nutrient-deficient. Current-year needles were sampled from the upper third of the crown (Lavender 1970) of trees judged to exhibit typical health for the plot. Five trees per plot were sampled, with samples taken from two or three locations around the crown and combined as bulk samples at the tree level. The trees were too tall to be sampled from the ground with pruning poles, and therefore twelve-gauge, full-choke shotguns were used to shoot branches off the trees from the ground.

The samples were placed in plastic bags in coolers on ice and delivered to UGLS for analysis. The foliage was analysed for macro- (N, P, K) and micro-nutrients ( $\mathrm{Fe}, \mathrm{Mn}, \mathrm{Mg}, \mathrm{Ca}$, $\mathrm{Zn}, \mathrm{B}, \mathrm{Cu})$ according to standard operating protocols of UGLS. The resulting nutrient levels were compared with those reported in the literature as critical for healthy red pine growth (e.g., Stone 1953, Mader 1971, Swan 1972, Morrison 1974, Ballard 1986, Bockheim et al. 1989, Carter 1992, Brockley 2001, Moore et al. 2004).

\section{Statistical analysis}

Data were tested for normality with the Shapiro-Wilk Test and when normally distributed (tree height and diameter) were subjected to analysis of variance (ANOVA) using PROC GLM and t-tests with PROC LSMEANS (SAS Institute, Cary, NC). Data that was not normally distributed (root and soil depth) was analysed with PROC NPAR1WAY WILCOXON (Kruskal-Wallis one-way analysis of variance by ranks). For all statistical tests the Type I error was set at 0.05 .

\section{Results}

\section{Tree mortality factors}

Four known and one previously unreported red pine mortality factors were investigated (Table 2). Armillaria ostoyae (Romagn.) Herink was identified as the principal mortality factor at four sites and was also causing mortality at the black pineleaf scale site and at one of two Annosus root rot sites. It was also observed on roots of trees at the three healthy sites, but was not causing observable disease symptoms. Although expanding mortality centres were the usual expression of disease, on the Baxter 249b site scattered windthrow of living trees was also observed. On these trees A. ostoyae had decayed the larger sinker roots, compromising the tree's stability (Fig. 3).

Water deficit (possibly combined with bark beetle attack) was determined as the cause of death at the northernmost site (Gurd Pr18, Parry Sound District). A thick layer of coarse gravel underlying the dead trees provided further evidence to support this diagnosis. Root disease pathogens were not found at this site.

The 38-year-old Grey-Sauble plantation 89/11 in Bruce County exhibited symptoms typical of iron deficiencychlorosis and crown dieback. Although chlorosis of the current year's foliage was evident throughout the plantation, a large spreading mortality centre and small clusters of dead trees were observed in one part. At this site the water table was approximately $1.5 \mathrm{~m}$ deep and unlike other sites, the soil reaction was alkaline in all horizons.

At the Brookdale 8a site in the Durham Region, mortality was observed in an area lacking signs or symptoms of root disease although Armillaria root disease was evident in other parts of the site. Trees heavily infested with black pineleaf scale (Nuculaspis californica [Coleman]) were dying in a large and rapidly expanding centre. Scale density on some needles was as high as 10 per $\mathrm{cm}$. This pest had been reported previ- 
Table 2. Causes of pocket mortality of red pine identified at study sites in southern Ontario ( $\mathrm{n}=21$ plots at 12 sites)

\begin{tabular}{ll}
\hline Mortality factor (causal agent) & County - site \\
\hline Armillaria root disease (Armillaria ostoyae) & Simcoe - Baxter 249b \\
& Simcoe - Phelpston 165b \\
& Simcoe - Baxter 243b-N (healthy site) \\
& Simcoe - Baxter 243b-S (healthy site) \\
& Simcoe - Phelpston 162e (healthy site) \\
& Dufferin - Randwick 1 \\
& Northumberland - Ganaraska 7b \\
& Norfolk - Miller Lumber site \\
Annosus root rot (Heterobasidion annosum) & York - North 30b \\
& Parry Sound - Gurd Tree Improvement Area Pr18 \\
Water deficit & Bruce - Grey-Sauble 89/11 \\
Nutrient deficiency (iron) & Durham - Brookdale 8 $\mathrm{a}^{\mathrm{b}}$ \\
\hline
\end{tabular}

aSite without disease, but A. ostoyae rhizomorphs were found on roots of asymptomatic trees

${ }^{\mathrm{b}}$ Mortality due to A. ostoyae was also observed but not in study plots

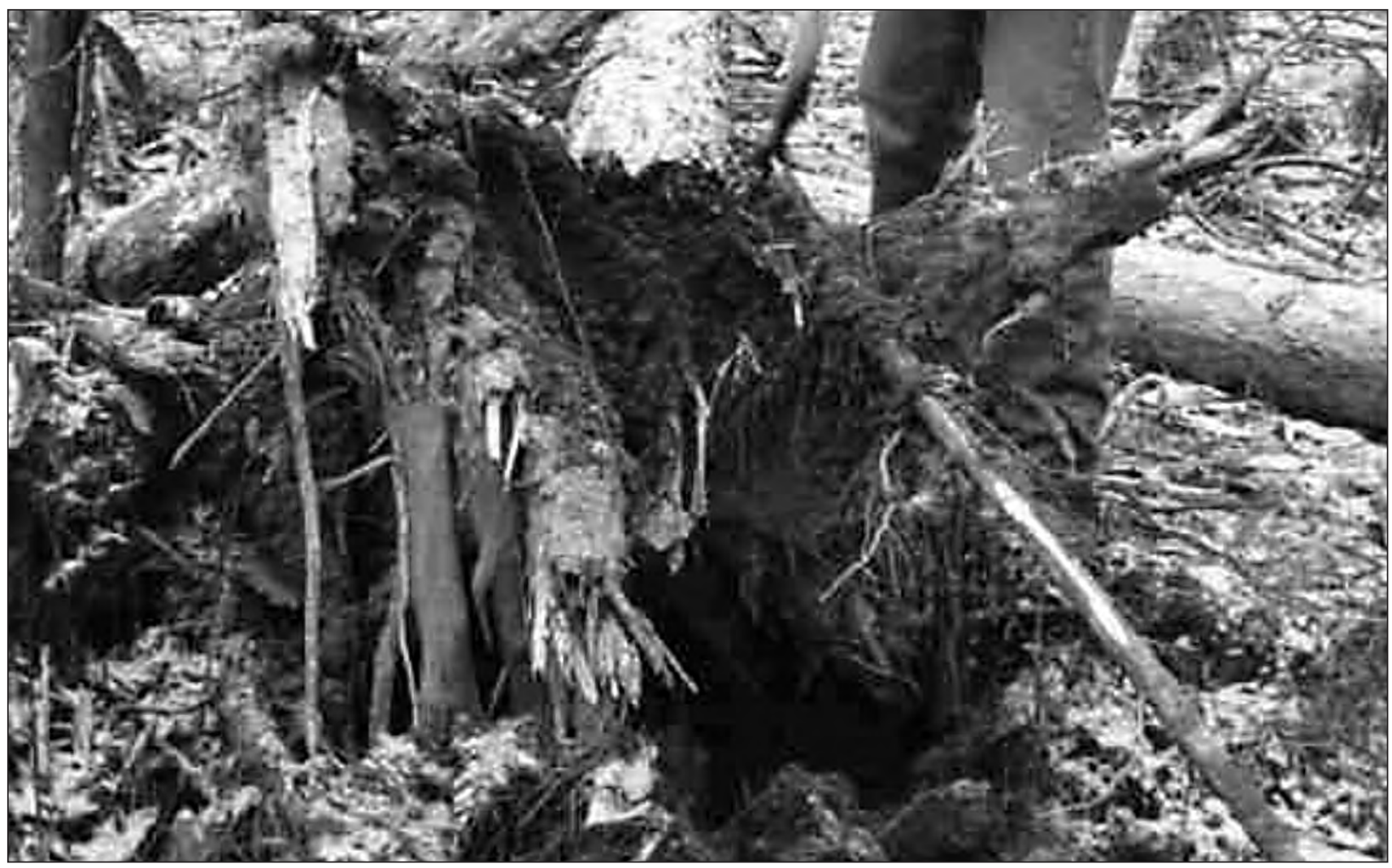

Fig. 3. Windthrown red pine with sinker and lateral roots decayed by Armillaria ostoyae. (Photo courtesy of Richard Wilson)

ously only once in Ontario (in 2003) at a location approximately $25 \mathrm{~km}$ east of the study site where it was observed causing minimal damage to red pine (K. Nystrom, Natural Resources Canada, personal communication, 2005).

Tree growth on mortality sites

Tree growth in asymptomatic and mortality plots was compared among sites. On sites with Armillaria root disease mor- tality, trees in the mortality plots were significantly larger in both height $(22.1 \mathrm{~m})$ and $\mathrm{DBH}(30.7 \mathrm{~cm})$ than trees in the asymptomatic plots $(20.8 \mathrm{~m}$ and $29.0 \mathrm{~cm})$. On sites with mortality caused by other factors mean tree height was greater in the asymptomatic plots, but DBH either did not differ or was greater in the asymptomatic plot (Table 3). Within mortality plots significant differences in diameter were not detected between live and recently dead trees, except for the Armillaria 
Table 3. Tree diameters (DBH) and heights in plots with asymptomatic (A-plot) vs. those with dead trees (M-plot), by biotic and abiotic caused red pine mortality.

\begin{tabular}{|c|c|c|c|c|c|c|}
\hline \multirow[b]{2}{*}{ Mortality factor } & \multicolumn{3}{|c|}{$\mathrm{DBH}(\mathrm{cm})$} & \multicolumn{3}{|c|}{ height (m) } \\
\hline & $\begin{array}{c}\text { A-plot } \\
\text { (n) }\end{array}$ & $\begin{array}{c}\text { M-plot } \\
\text { (n) }\end{array}$ & p value ${ }^{a}$ & $\begin{array}{c}\text { A-plot } \\
\text { (n) }\end{array}$ & $\begin{array}{c}\text { M-plot } \\
\text { (n) }\end{array}$ & $p$ value \\
\hline Armillaria root disease & $\begin{array}{l}29.0 \\
\left(55^{\mathrm{b}}\right)\end{array}$ & $\begin{array}{l}30.7 \\
(51)\end{array}$ & $\begin{array}{c}<0.01 \\
-\end{array}$ & $\begin{array}{l}20.8 \\
(55)\end{array}$ & $\begin{array}{l}22.1 \\
(47)\end{array}$ & $\begin{array}{c}<0.01 \\
-\end{array}$ \\
\hline Annosus root rot & $\begin{array}{l}32.3 \\
(29)\end{array}$ & $\begin{array}{l}28.9 \\
(31)\end{array}$ & $\begin{array}{c}<0.01 \\
-\end{array}$ & $\begin{array}{l}25.6 \\
(29)\end{array}$ & $\begin{array}{l}24.2 \\
(30)\end{array}$ & $\begin{array}{c}<0.01 \\
-\end{array}$ \\
\hline Water deficit & $\begin{array}{l}20.5 \\
(25)\end{array}$ & $\begin{array}{l}18.8 \\
(23)\end{array}$ & $\begin{array}{c}0.03 \\
-\end{array}$ & $\begin{array}{l}14.9 \\
(25)\end{array}$ & $\begin{array}{l}13.6 \\
(18)\end{array}$ & $\begin{array}{c}<0.01 \\
-\end{array}$ \\
\hline Nutrient deficiency (iron) & $\begin{array}{l}19.7 \\
(26)\end{array}$ & $\begin{array}{l}18.2 \\
(52)\end{array}$ & $\begin{array}{c}\mathrm{nsd}^{\mathrm{c}} \\
-\end{array}$ & $\begin{array}{l}18.1 \\
(10)\end{array}$ & $\begin{array}{l}17.0 \\
(16)\end{array}$ & $\begin{array}{c}<0.01 \\
-\end{array}$ \\
\hline Black pineleaf scale & $\begin{array}{l}28.8 \\
(17)\end{array}$ & $\begin{array}{c}30.5 \\
(16)\end{array}$ & $\begin{array}{c}\text { nsd } \\
-\end{array}$ & $\begin{array}{l}22.1 \\
(17)\end{array}$ & $\begin{array}{l}21.5 \\
(16)\end{array}$ & $\begin{array}{c}0.003 \\
-\end{array}$ \\
\hline
\end{tabular}

abased on Analysis of Variance

bnumber of trees measured

${ }^{c_{n s d}}=$ not significantly different

Table 4. Diameters and heights of live vs. standing recently dead trees in mortality plots by biotic and abiotic caused red pine mortality

\begin{tabular}{|c|c|c|c|c|c|c|}
\hline Mortality factor & live & $\begin{array}{c}\text { DBH }(\mathrm{cm}) \\
(\mathbf{n}) \\
\text { dead }\end{array}$ & p value ${ }^{a}$ & live & $\begin{array}{c}\text { height }(\mathbf{m}) \\
(\mathbf{n}) \\
\text { dead }\end{array}$ & p value \\
\hline Armillaria root disease & $\begin{array}{l}31.1 \\
\left(42^{b}\right)\end{array}$ & $\begin{array}{c}28.6 \\
(9)\end{array}$ & $\begin{array}{c}0.03 \\
-\end{array}$ & $\begin{array}{c}22.21 \\
\left(30^{c}\right)\end{array}$ & $\begin{array}{c}20.50 \\
(6)\end{array}$ & $\begin{array}{c}\text { nsd } \\
-\end{array}$ \\
\hline Annosus root rot & $\begin{array}{l}29.4 \\
(25)\end{array}$ & $\begin{array}{c}26.9 \\
(6)\end{array}$ & $\begin{array}{c}\mathrm{nsd}^{\mathrm{d}} \\
-\end{array}$ & $\begin{array}{c}24.36 \\
(25)\end{array}$ & $\begin{array}{c}23.71 \\
(5)\end{array}$ & $\begin{array}{c}0.04 \\
-\end{array}$ \\
\hline Water deficit & $\begin{array}{l}19.0 \\
(18)\end{array}$ & $\begin{array}{c}18.0 \\
(5)\end{array}$ & $\begin{array}{c}\text { nsd } \\
-\end{array}$ & $\begin{array}{c}13.63 \\
(18)\end{array}$ & $\begin{array}{l}-^{\mathrm{e}} \\
-\end{array}$ & - \\
\hline Nutrient deficiency (iron) & $\begin{array}{l}18.2 \\
(48)\end{array}$ & $\begin{array}{c}18.3 \\
(4)\end{array}$ & $\begin{array}{c}\text { nsd } \\
-\end{array}$ & $\begin{array}{c}16.91 \\
(13)\end{array}$ & $\begin{array}{c}17.75 \\
(1)\end{array}$ & $\begin{array}{c}\text { nsd } \\
-\end{array}$ \\
\hline Black pineleaf scale & $\begin{array}{l}31.3 \\
(11)\end{array}$ & $\begin{array}{c}28.7 \\
(5)\end{array}$ & $\begin{array}{c}\text { nsd } \\
-\end{array}$ & $\begin{array}{c}21.56 \\
\text { (11) }\end{array}$ & $\begin{array}{c}21.26 \\
(5)\end{array}$ & $\begin{array}{c}\text { nsd } \\
-\end{array}$ \\
\hline
\end{tabular}

abased on Analysis of Variance

b number of trees measured

${ }^{\mathrm{c}}$ Dufferin site excluded because heights of dead trees could not be measured because tops were broken

$\mathrm{d}_{\text {nsd }}=$ not significantly different

${ }^{e}$ no height measurements because tops of dead trees were broken

sites where live trees were larger in DBH $(31.1 \mathrm{~cm}$ versus 28.6 cm; Table 4).

Analysis of BAI revealed that on the Armillaria root disease sites trees that died were the larger, more vigorously growing trees during the first eight to 14 years on the Ganaraska Forest 7b, Randwick 1, and Phelpston 165b sites, and for the first 35 years on the Baxter 249b site, after which their growth rate fell below that of the healthy trees. The trees that died then exhibited a four- to eight-year growth surge fol- lowing a thinning entry in the early 1990s, before their rapid decline and death over a two- to five-year period (Fig. 4). Results at the other sites varied. At the annosus root rot site, York Region North 30b, and the black pineleaf scale site, Brookdale 8a, the growth rates of trees in mortality plots that eventually died were significantly less than those of healthy trees, while the opposite trend was observed at the sites deemed nutrient-deficient (Grey-Sauble 89/11) and waterdeficient (Gurd 7b) (Fig. 5). 

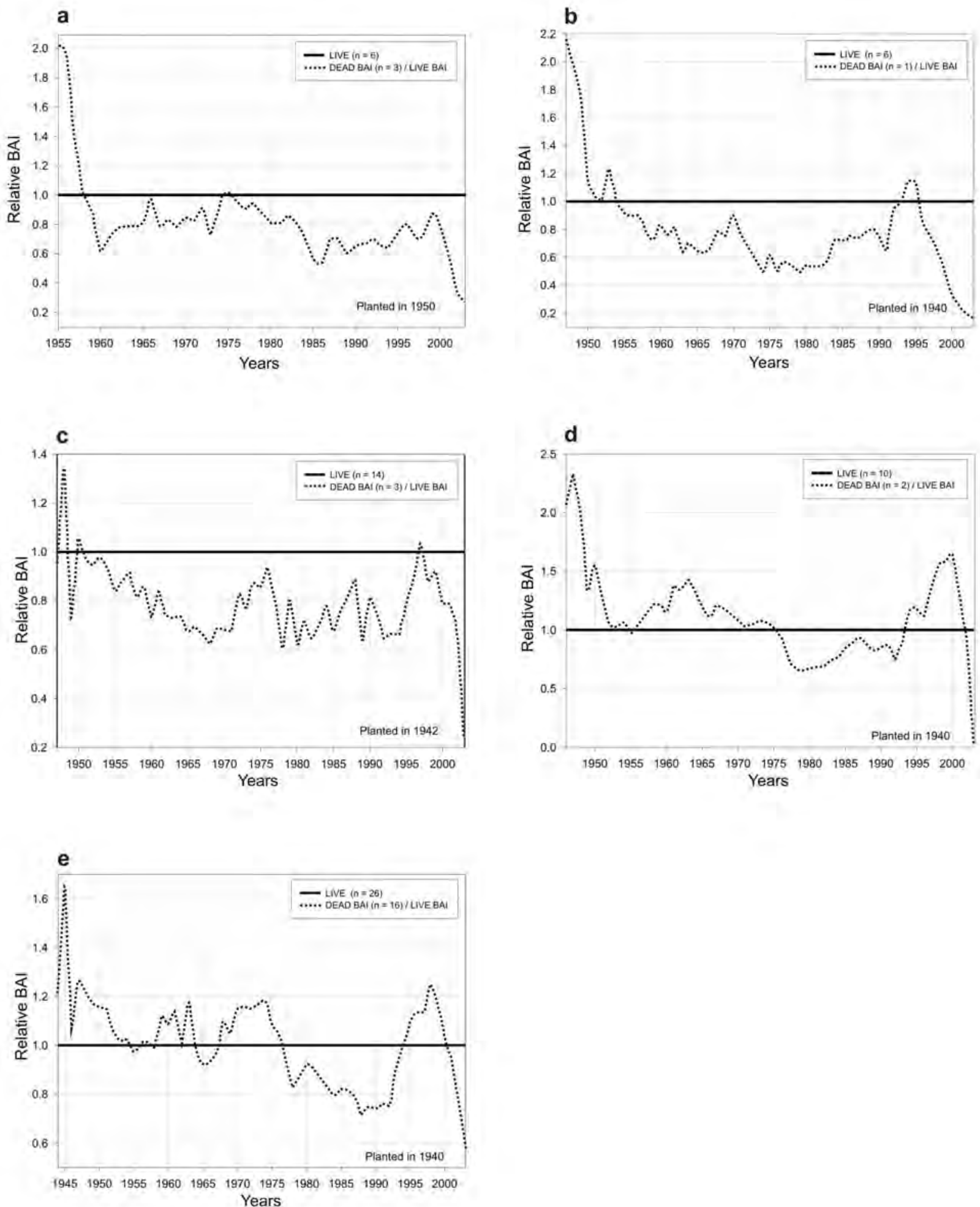

Fig. 4. Relative radial growth (basal area index - BAl) of red pine trees in study plots with Armillaria root disease-caused mortality in four plantations: (a) Ganaraska 7b, (b) Randwick 1, (c) Phelpston 165b, (d) Baxter 249b, and (e) throughout the Baxter 249b plantation. 
a
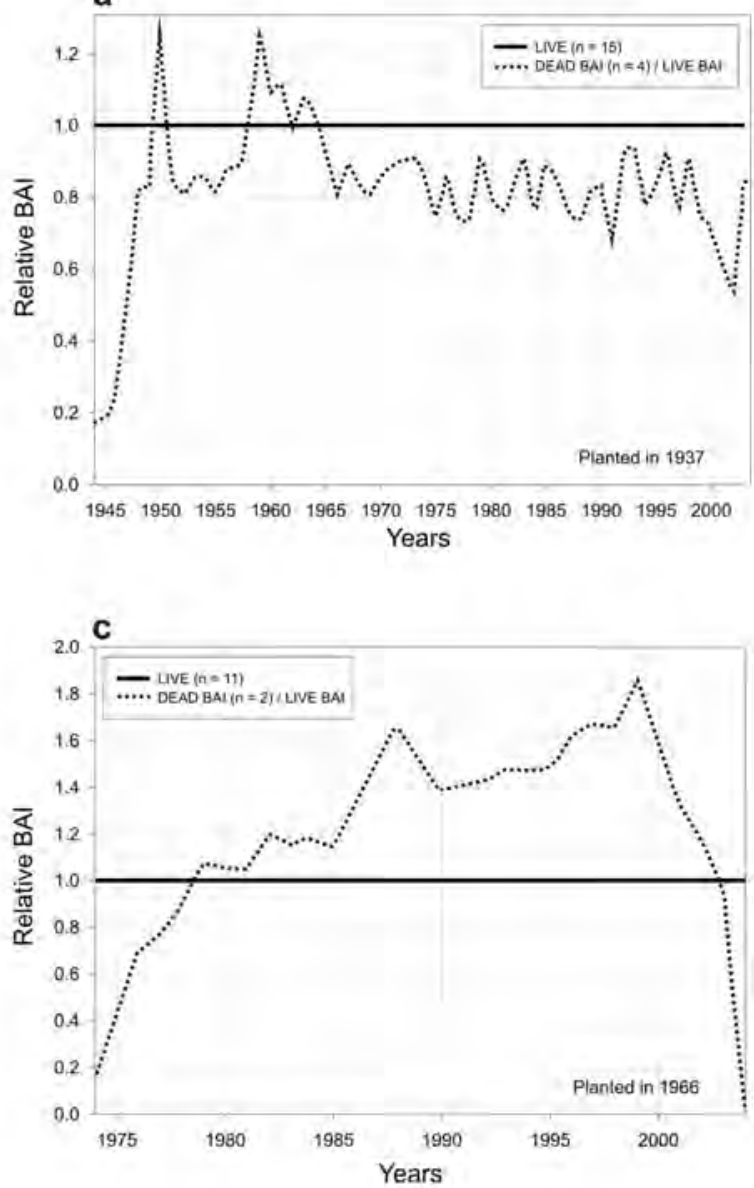

b
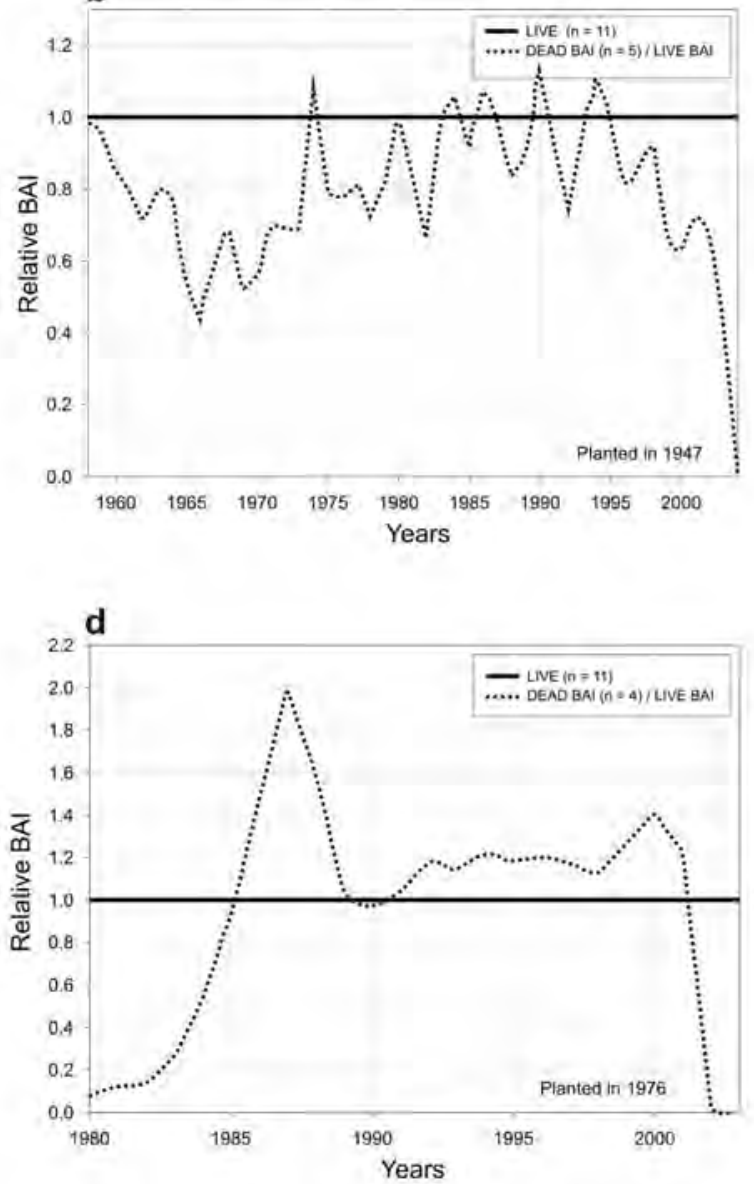

Fig. 5. Relative radial growth (basal area index - BAl) for red pine trees in plots: (a) with annosus root rot at study site North $30 b$, (b) with black pineleaf scale (Nuculaspis californica [Coleman]) at the Brookdale 8a site, (c) with nutrient deficiency (iron) at the GreySauble 89/11 site, and (d) water deficit at the Gurd Tree Improvement Area Pr18 site.

\section{Belowground attributes Soil horizon depth}

The combined depth of the A and B soil horizons did not differ between healthy sites $(117 \mathrm{~cm}, \mathrm{n}=3)$ and disease sites $(110$ $\mathrm{cm}, \mathrm{n}=9$ ), nor did it differ between asymptomatic and mortality plots on disease sites. When the data were partitioned by mortality factor, however, the combined A and B horizons on the nutrient-deficient, Armillaria, and water-deficit sites were significantly deeper in the asymptomatic plots than in the mortality plots (Table 5).

\section{Rooting depth}

The mean rooting depth on healthy sites (where epiphytic growth of Armillaria ostoyae was observed but disease symptoms not evident) was $195 \mathrm{~cm}$, significantly deeper than the $143 \mathrm{~cm}(\mathrm{p}<0.0001)$ observed on all diseased sites (Fig. 6), and the 164-cm mean rooting depth on the Armillaria mortality sites. On diseased sites rooting depth did not differ between asymptomatic $(145 \mathrm{~cm})$ and mortality plots $(142$ $\mathrm{cm})$, nor between asymptomatic and mortality plots when the data were partitioned by mortality factor. The rooting depth of living trees $(144 \mathrm{~cm})$ was not greater than that of trees that died $(140 \mathrm{~cm})$. When the data were partitioned by mortality factor, living trees in the Armillaria mortality plots were found to be more deeply rooted $(169 \mathrm{~cm})$ than those that later died $(154 \mathrm{~cm})$. On the black pineleaf scale site, the trees that died were actually more deeply rooted than the live trees in the mortality plot (Table 6). On sites with an alkaline $C$ soil horizon, most of the rooting was limited to the $\mathrm{A}$ and $\mathrm{B}$ horizons (Fig. 2). Root tips at the acidic-alkaline horizon interface were frequently thickened and encrusted with calcium carbonate $\left(\mathrm{CaCO}_{3}\right)$ deposits (Fig. 7).

\section{Soil texture, $\mathrm{pH}$, and bulk density}

Soil texture on all sites was sandy, typical of sites chosen for red pine plantations, and although some heavier-textured soil was encountered as small pockets or lenses, the soil texture was mostly sand to sandy loam. On the Ganaraska $7 \mathrm{~b}$ site, a thick gravel layer was present under much of the mortality plot, in some places comprising the entire layer between the 
Table 5. Depth of the A and B soil horizons by mortality factor in red pine research plots, compared between asymptomatic (A-plot) and mortality (M-plot) plots and within mortality plots between live and dead trees

\begin{tabular}{|c|c|c|c|c|c|c|}
\hline \multirow[b]{3}{*}{ Mortality factor/Study site } & \multicolumn{6}{|c|}{ Combined depth of A and B horizons (cm) } \\
\hline & \multicolumn{3}{|c|}{ Between plot types $^{\mathrm{a}}$} & \multicolumn{3}{|c|}{ By tree status ${ }^{b}$} \\
\hline & A-plot & M-plot & p value ${ }^{c}$ & live & dead & $p$ value \\
\hline \multicolumn{7}{|l|}{ All factors } \\
\hline all sites with disease & 114 & 107 & $\mathrm{nsd}^{\mathrm{d}}$ & 102 & 110 & nsd \\
\hline \multicolumn{7}{|l|}{ Armillaria root disease } \\
\hline all sites with disease & 148 & 134 & 0.04 & 129 & 138 & nsd \\
\hline Baxter 249b & 202 & 190 & 0.02 & 189 & 190 & nsd \\
\hline Phelpston 165b & 132 & 153 & $<0.01$ & 150 & 154 & nsd \\
\hline Randwick 1 & 193 & 123 & $<0.01$ & 103 & 170 & $<0.01$ \\
\hline Ganaraska 7b & 60 & 48 & $<0.01$ & 42 & 51 & nsd \\
\hline \multicolumn{7}{|l|}{ Annosus root rot } \\
\hline all sites with disease & 110 & 114 & nsd & 103 & 123 & 0.04 \\
\hline Norfolk County & 142 & 148 & nsd & 140 & 154 & nsd \\
\hline York Region, North 30b & 74 & 85 & nsd & 78 & 92 & nsd \\
\hline \multicolumn{7}{|l|}{ Water deficit } \\
\hline $\begin{array}{l}\text { Gurd Tree Improvement } \\
\text { Area Pr18 }\end{array}$ & 60 & 43 & $<0.01$ & 44 & 43 & nsd \\
\hline \multicolumn{7}{|l|}{ Nutrient deficiency (iron) } \\
\hline Grey-Sauble 89/11 & 63 & 51 & 0.01 & 53 & 50 & nsd \\
\hline \multicolumn{7}{|l|}{ Black pineleaf scale } \\
\hline Brookdale 8a & 83 & 104 & nsd & 75 & 117 & 0.03 \\
\hline
\end{tabular}

${ }^{\text {a }}$ mean values based on 21-30 trees in A-plots and 29-52 trees in M-plots

b mean values based on 23-59 live trees and 11-26 dead trees within M-plots

cbased on Kruskal-Wallis test

$\mathrm{d}_{\text {nsd }}=$ not significantly different

A and sandy-to-sandy loam C horizon. The gravel layer was also found under the asymptomatic plot but at a greater depth, with a deeper combined A and B horizon than under the mortality plot. This condition was also observed in the mortality plot on the Gurd Pr18 site.

The soil bulk density $\left(\mathrm{g} \mathrm{ml}^{-1}\right)$ of the main rooting zone, the $\mathrm{A}$ and $\mathrm{B}$ horizons, was significantly higher on diseased sites (1.29) than on healthy sites $(1.22)(\mathrm{p}=0.0017)$ but was not high enough to suggest soil compaction. The bulk density of the $\mathrm{C}$ horizon on healthy (1.41) and diseased sites (1.46) did not differ significantly.

Soil texture, $\mathrm{pH}$ and bulk density did not differ between the asymptomatic plots and mortality plots within most of the sites. The most notable difference between healthy and diseased sites was the $\mathrm{pH}$ of the $\mathrm{C}$ horizon. On sites with mortality, the $\mathrm{C}$ horizon was slightly to strongly alkaline while on sites without disease it was slightly acidic or neutral (Fig. 8).

\section{Soil nutrient analysis}

On most sites, rooting was most abundant in, and sometimes restricted to, the $\mathrm{A}$ and $\mathrm{B}$ horizons. Although variants within major soil horizons (e.g., B1, B2) were sometimes detected these were treated as samples of the principal horizon. The most notable differences between the healthy and diseased sites were in the levels of $\mathrm{P}, \mathrm{Mg}$, and $\mathrm{Ca}$ in the $\mathrm{C}$ horizon. Much more $\mathrm{P}$ was extracted from the soil $\mathrm{C}$ horizon on the healthy sites than on diseased sites ( 16.5 vs. $0.91 \mathrm{mg} \mathrm{kg}^{-1}$ ).
Conversely, the $\mathrm{C}$ horizon of the diseased sites had significantly more $\mathrm{Mg}$ ( 68.5 vs. $4.7 \mathrm{mg} \mathrm{kg}^{-1}$ ) and $\mathrm{Ca}$ (5475 vs $53 \mathrm{mg}$ $\mathrm{kg}^{-1}$ ) than the healthy sites.

\section{Mycorrhizal colonization}

On red pine roots, non-mycorrhizal root tips and three main types of ectomycorrhizae were observed. One type of ectomycorrhizal root tip had a thin, whitish mantle and appeared brown under the microscope; another exhibited a thick, black, hairy mantle and appeared black under the microscope; the third was very white with obvious white hairs projecting from the structures.

Mycorrhizal development (i.e., mycorrhizal tips per $\mathrm{cm}$ of fine root) on healthy sites $\left(1.64 \mathrm{~cm}^{-1}\right)$ was no greater than that on diseased sites $\left(1.66 \mathrm{~cm}^{-1}\right)$. However, on disease sites, trees in asymptomatic plots averaged significantly more mycorrhizal development $\left(1.81 \mathrm{~cm}^{-1}\right)$ than trees in mortality plots $\left(1.50 \mathrm{~cm}^{-1}\right)$. The greatest between-plot difference occurred on the Brookdale 8a black pineleaf scale site (Table 7), where many of the trees in the mortality plot exhibiting distinct symptoms of decline had 0.32 mycorrhizal tips per cm compared to $1.54 \mathrm{~cm}^{-1}$ for asymptomatic plots.

\section{Foliar nutrient levels}

Published literature was surveyed for threshold foliar nutrient levels considered critical for healthy red pine growth. Four of seven sites sampled, including the three healthy sites, had foliar Fe levels at or very close to the critical level while one 


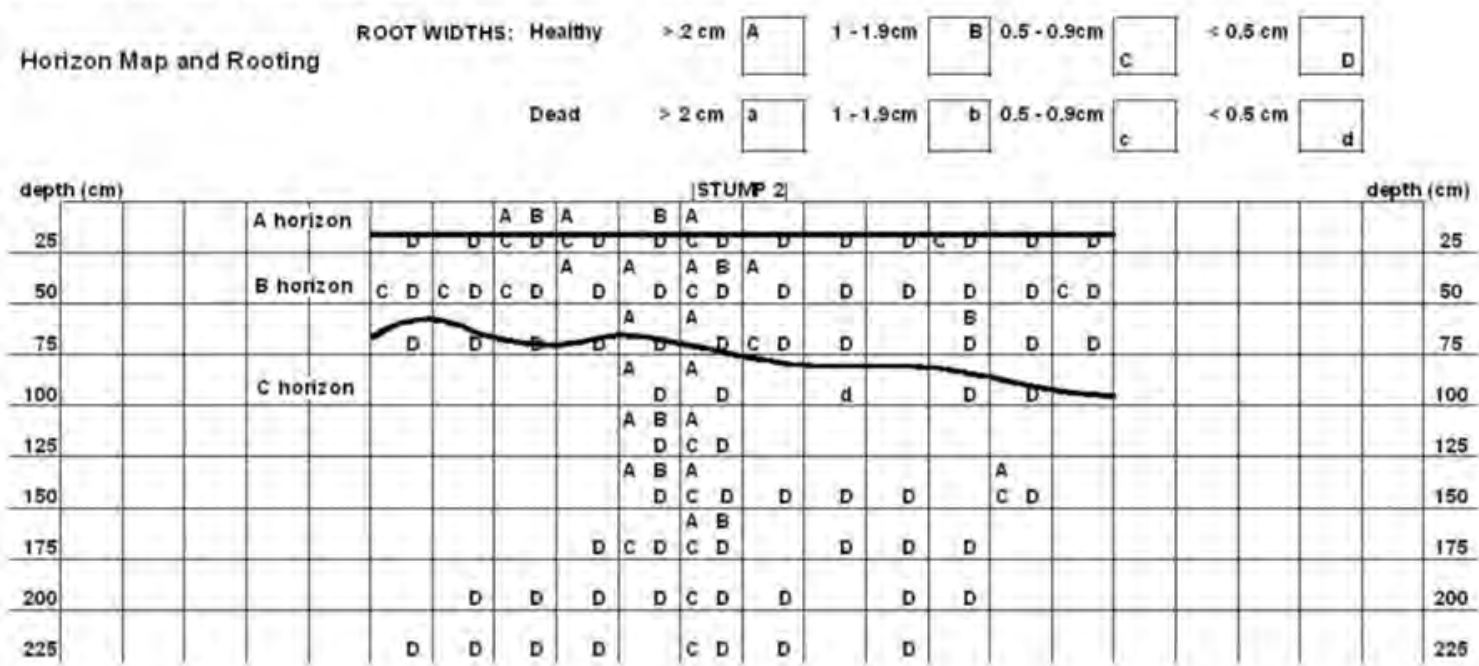

b

YORK REGION NORTH 30b M PIOT TREE \#4 (dead)
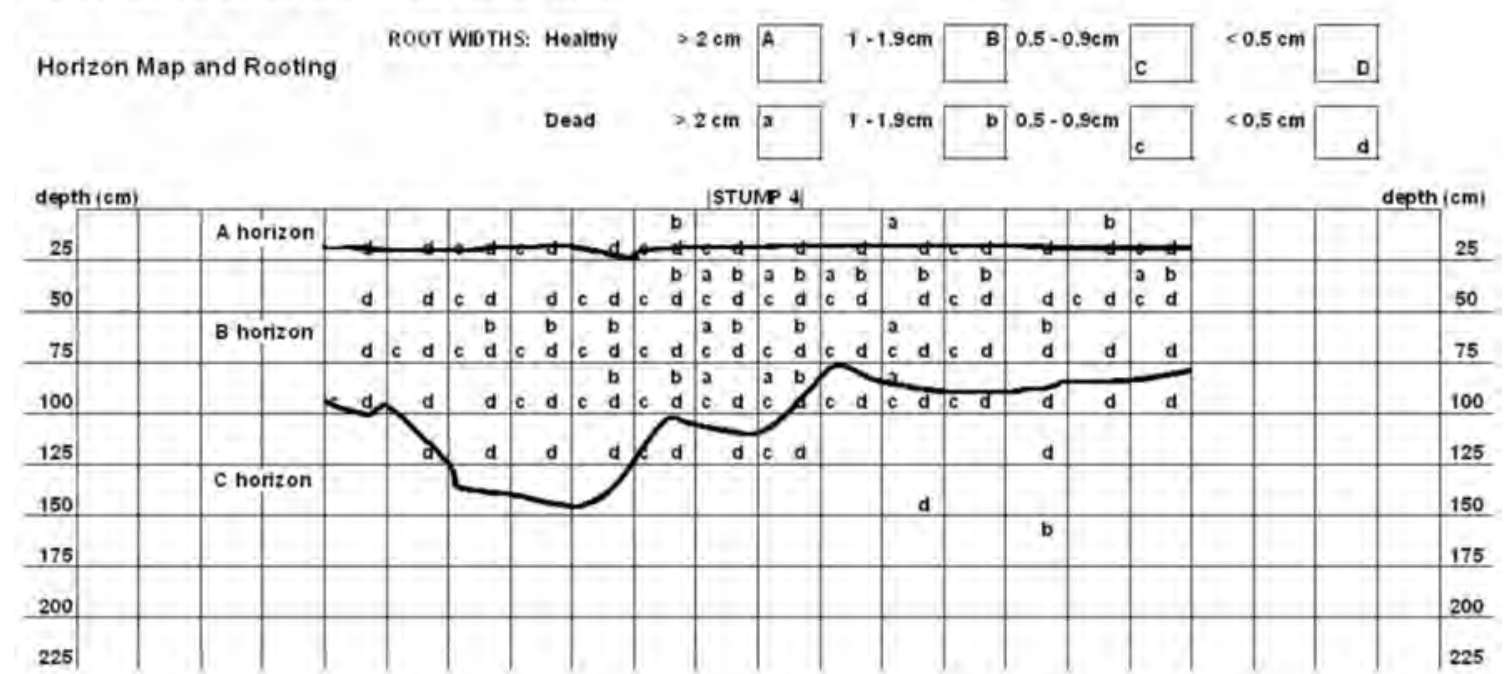

Fig. 6. Soil horizon and rooting schematic for (a) a healthy tree on a site without disease that has an acidic $\mathrm{C}$ horizon and (b) a dead red pine tree on a site with disease and an alkaline $C$ horizon.

site, Grey-Sauble 89/11, which exhibited chlorosis and dieback, had Fe levels below the putative critical level in both the asymptomatic and mortality plots (Table 8).

\section{Discussion}

\section{Armillaria root disease}

The predominance of Armillaria ostoyae as a mortality factor in the red pine plantations is not surprising. Earlier studies (Whitney 1988; McLaughlin 2001a, b) reported its association with red pine mortality. Since most of the red pine plantations were established on former agricultural land the origin of inoculum at the various sites is of interest. With removal of forest cover and stumps in the late 1800s and a period of pasture or cultivation for agricultural crops before red pine plantings throughout the early to mid 1900s, it is often assumed that the plantations were established on sites cleansed of Armillaria inoculum. A recent Armillaria population study (McLaughlin 2008) showed, however, that the inoculum may be carried through the agricultural period on residual root material from the original forest cover since the size of the genets was greater than the postulated rhizomorph expansion rate during the post-deforestation era. The longevity of inoculum on residual roots and stumps has been demonstrated by Rishbeth (1972), who found that Armillaria mellea sensu lato could still produce rhizomorphs from oak stumps 40 years after felling. 
Table 6. Red pine rooting depth in asymptomatic (A-plot) and mortality (M-plot) plots on diseased sites with various biotic and abiotic mortality factors

\begin{tabular}{|c|c|c|c|c|c|c|}
\hline \multirow[b]{3}{*}{ Mortality factor/Study site } & \multicolumn{6}{|c|}{ Rooting depth $(\mathrm{cm})$} \\
\hline & \multicolumn{3}{|c|}{ Between plot types ${ }^{\mathrm{a}}$} & \multicolumn{3}{|c|}{ By tree status ${ }^{b}$} \\
\hline & A-plot & M-plot & p value ${ }^{c}$ & live & dead & p value \\
\hline \multicolumn{7}{|l|}{ All factors } \\
\hline all sites with disease & 145 & 142 & $\mathrm{nsd}^{\mathrm{d}}$ & 144 & 140 & nsd \\
\hline \multicolumn{7}{|l|}{ Armillaria root disease } \\
\hline all sites with Armillaria root disease & 169 & 161 & nsd & 169 & 154 & 0.02 \\
\hline Baxter $249 b$ & 197 & 164 & $<0.01$ & 183 & 146 & $<0.01$ \\
\hline Phelpston 165b & 151 & 179 & $<0.01$ & 188 & 175 & nsd \\
\hline Randwick 1 & 184 & 143 & $<0.01$ & 147 & 131 & nsd \\
\hline Ganaraska 7b & 140 & 160 & nsd & 178 & 153 & nsd \\
\hline \multicolumn{7}{|l|}{ Annosus root rot } \\
\hline all sites with annosus root rot & 122 & 123 & nsd & 115 & 130 & nsd \\
\hline Norfolk County & 131 & 151 & nsd & 151 & 150 & nsd \\
\hline York Region, North 30b & 112 & 99 & nsd & 89 & 109 & $<0.01$ \\
\hline \multicolumn{7}{|l|}{ Water deficit } \\
\hline Gurd Tree Improvement Area Pr18 & 120 & 136 & nsd & 139 & 133 & nsd \\
\hline \multicolumn{7}{|l|}{ Nutrient deficiency (iron) } \\
\hline Grey-Sauble 89/11 & 133 & 119 & 0.04 & 124 & 109 & nsd \\
\hline $\begin{array}{c}\text { Black pineleaf scale } \\
\text { Brookdale } 8 \mathrm{a}\end{array}$ & 129 & 135 & nsd & 114 & 144 & 0.02 \\
\hline
\end{tabular}

${ }^{a}$ mean values based on $20-103$ trees in A-plots and 31-160 trees in M-plots

bmean values based on 9-44 live trees and 22-50 dead trees within M-plots

cbased on Kruskal-Wallis test

nsd = not significantly different

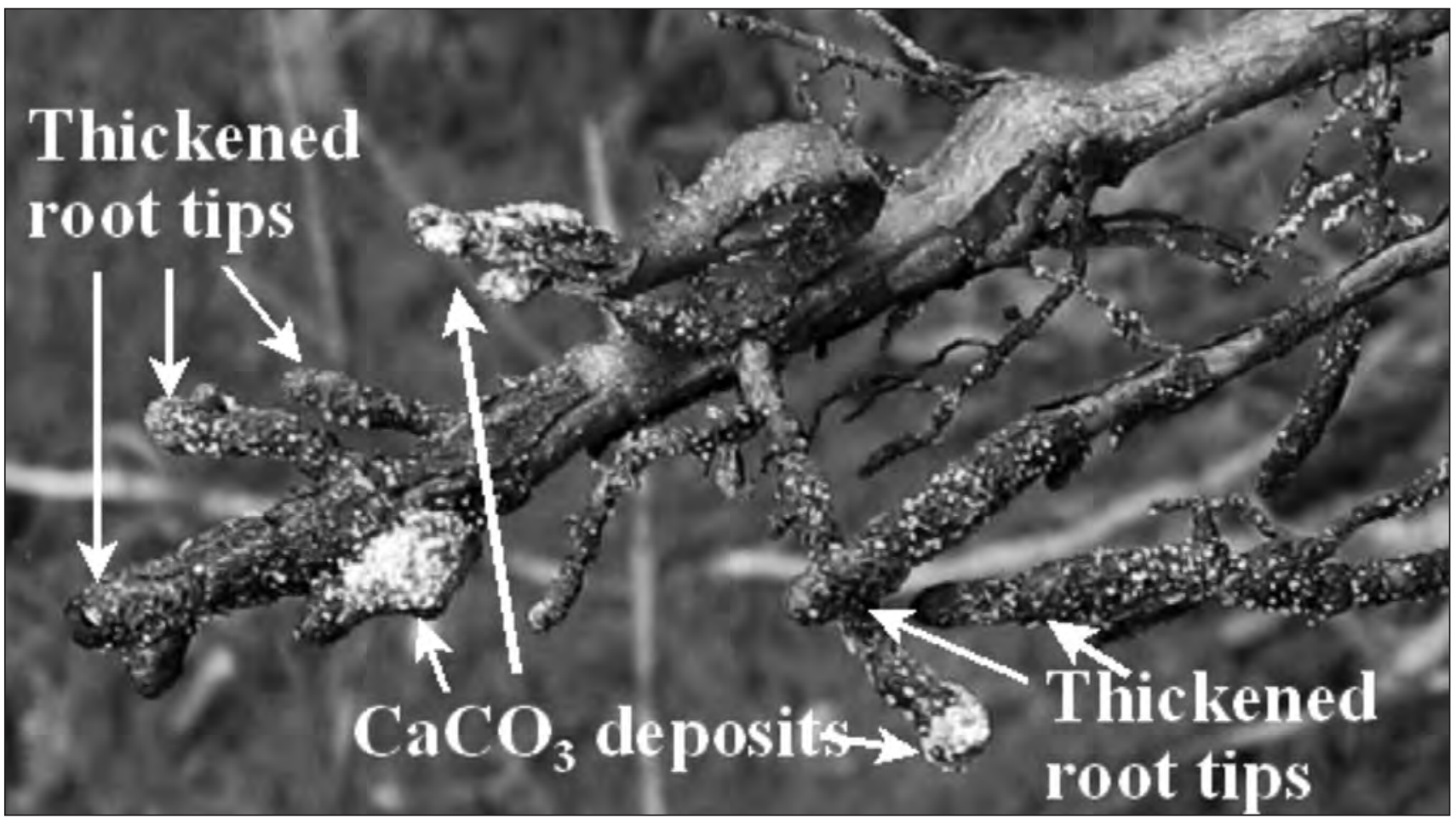

Fig. 7. Thickened root tips showing calcium carbonate $\left(\mathrm{CaCO}_{3}\right)$ deposits on a red pine tree growing at the Norfolk County site which has an alkaline $\mathrm{C}$ horizon . 


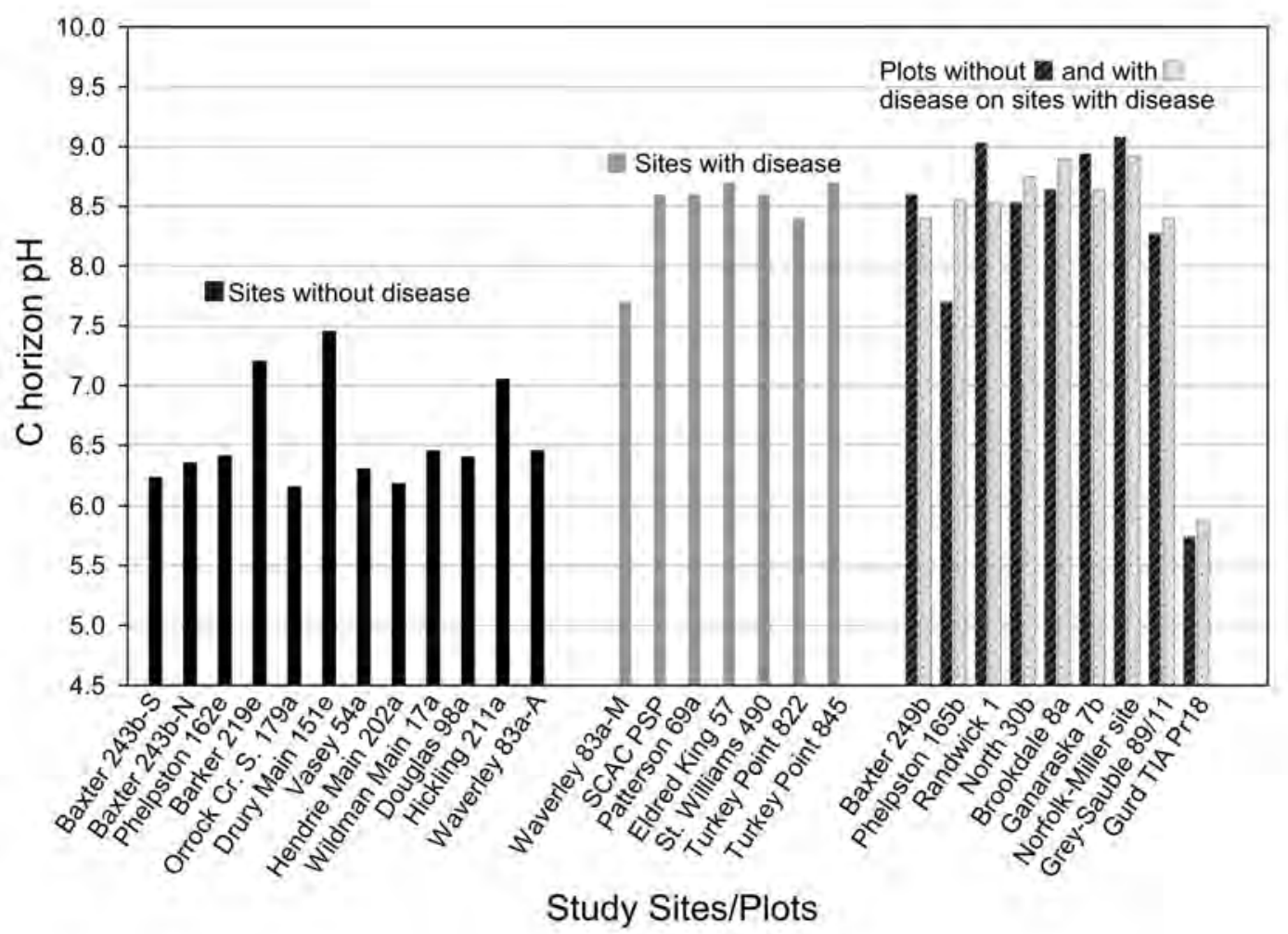

Fig. 8. Soil $\mathrm{C}$ horizon $\mathrm{pH}$ for sites and plots with asymptomatic and dying red pine trees.

The mean DBH and height of all trees in mortality plots on the Armillaria sites were greater than those in the asymptomatic plots, suggesting that the growing conditions were actually superior in diseased portions of the plantations, and that trees of low vigour (as expressed by lower growth rate) were not more susceptible to disease. However, on sites with other mortality factors, the $\mathrm{DBH}$ and height of trees were greater in asymptomatic plots than in mortality plots, providing evidence that growing conditions were superior in the asymptomatic plots, supporting the hypothesis that the less vigorous trees were more likely to die.

Deeper rooting was a consistent indicator of a healthier plantation at the site level. On sites with Armillaria root disease, however, the rooting depth of the individual tree relative to that of its immediate neighbours was more closely related to tree health than was mean rooting depth at the plot level. Healthy trees had roots on average $15 \mathrm{~cm}$ deeper than diseased trees. What effect this relatively small difference in rooting depth would have on tree health is difficult to determine, but drought is known to force trees to extract ground water from deeper soil horizons (Dawson 1996, Weltzin and McPherson 1997), and this $15-\mathrm{cm}$ difference may have become the critical difference between survival and mortality.

On Armillaria sites BAI better explained the differences between healthy trees and trees that died than did simple $\mathrm{DBH}$ and height measurements. The data show that the trees that died were the larger, more vigorously growing trees dur- ing the earliest years of the plantations and that before rapidly succumbing to Armillaria root disease they had experienced a surge in growth exceeding that of trees that survived. Mallet and Volney (1999) made similar observations that lodgepole pine (Pinus contorta Dougl. ex Loud. var. latifolia Engelm.) infected with Armillaria root disease initially grew better than non-infected trees outside disease centres. In a study in Oregon, USA, Armillaria root disease killed the largest, fastestgrowing Douglas-fir (Pseudotsuga menziesii [Mirb.] Franco var. menziesii) trees as well as less vigorous trees (Rosso and Hansen 1998). In another Douglas-fir study, Entry et al. (1991) had greater success in inoculating larger, more vigorously growing, nitrogen-fertilized trees. They hypothesized that higher leaf area and stem growth in more vigorous trees increased the ratio of sugars to phenolics in the roots, a condition which favours the pathogen (Wargo 1980; Kirk 1981, cited in Entry et al. 1991; Entry and Cromack 1988). Inverse correlations between increased growth resulting from $\mathrm{N}$ fertilization and the concentration of phenolic compounds in plant tissue have also been previously reported (Palo et al. 1985, Bryant et al. 1987). In our study, the foliar $\mathrm{N}$ level of trees in the mortality plots was higher than that of trees in the asymptomatic plots (Table 8).

\section{Annosus root rot}

Annosus root rot was first reported in Ontario in 1956 (Jorgensen 1956). It has been subsequently detected almost exclu- 
Table 7. Mycorrhizal development (tips per $\mathrm{cm}$ fine root, based on $120 \mathrm{~cm}$ of fine roots $<1 \mathrm{~mm}$ diameter] on red pine in asymptomatic and mortality plots on diseased sites

\begin{tabular}{lccccc}
\hline & \multicolumn{2}{c}{ Asymptomatic plot } & \multicolumn{2}{c}{ Mortality plot } & \\
\cline { 2 - 4 } Mortality factor & tips/cm & $\mathbf{n}^{\mathbf{a}}$ & tips/cm & $\mathbf{n}$ & p-value \\
\hline All sites combined & 1.81 & 140 & 1.50 & 133 & $<0.01$ \\
Armillaria root disease & 1.85 & 64 & 1.59 & 58 & 0.03 \\
Annosus root rot & 1.34 & 31 & 1.40 & 30 & nsd $^{\mathbf{c}}$ \\
Water deficiency & 2.03 & 13 & 2.20 & 13 & nsd \\
Nutrient deficiency (iron) & 2.68 & 16 & 1.93 & 16 & 0.02 \\
Black pineleaf scale & 1.54 & 16 & 0.32 & 16 & $<0.01$ \\
\hline
\end{tabular}

anumber of soil blocks assessed

b based on Analysis of Variance

${ }^{c}$ not significantly different

sively in native species conifer plantations in south-central and eastern Ontario (Czerwinski et al. 1998) but its range and effect on natural forests in the region have yet to be determined. Only the P group has so far been found in Ontario (Raffle and Hsiang 1995). In our study the growth rate of the trees that later died averaged slightly less than that of living trees from 1944 to 1965 but from 1965 until they died in 2003, the BAI of these trees diverged from that of healthy trees at an increasing rate (Fig. 5a). Similar observations of long-term growth reduction associated with Heterobasidion annosum infection were made in the United States by Froelich et al. (1977) for slash pine (Pinus elliottii var. elliottii Engelm.) and, by Bendz-Hellgren and Stenlid (1997) for Norway spruce (Picea abies [L.] Karst.) in Sweden. The growth rate data from the annosus root rot sites in the current study show a typical post-infection trajectory for this disease but do not provide strong evidence that the trees that died from annosus root rot were particularly disadvantaged at the time of infection. These trees did, however, have growth rates inferior to the healthy trees over much of their life.

\section{Moisture deficiency}

At the moisture deficient site, Gurd Pr18, the main difference between the asymptomatic and mortality plots was the greater combined depth of the A and B soil horizons in the asymptomatic plot. The deeper $\mathrm{A}$ and $\mathrm{B}$ horizons and underlying compacted finer-textured soil horizons of the asymptomatic plot provided a larger volume of soil with better moisture retention than was available to the trees in the mortality plot, thus increasing the drought tolerance of trees in the asymptomatic plot and reducing the risk of bark beetle attack (Richards et al. 1962). These soil conditions may also help to explain the greater DBH, height, and BAI growth in the asymptomatic plot. Radial growth and shoot extension of red pine are influenced by the availability of water (Dils and Day 1952, Fayle and Pierpoint 1975).

The data do not explain the growth surge of the trees in the mortality plot that died during the 15 years prior to sampling (Fig. 5d), but perhaps the greater growth rate was accompanied by a greater demand for soil moisture, and this demand for either upper soil water or ground water could not be met on the microsites occupied by these trees during periods of drought.

\section{Nutrient deficiency}

Dieback and mortality of 30- to 35-year-old red pine in southern Ontario due to Fe and/or Mn deficiency has been reported by Ellis and Whitney (1975) in plantations established on calcareous tills of dolomite origin, similar to the Grey-Sauble 89/11 site investigated in our study. From Ellis and Whitney's report, as well as an unpublished study by

Table 8. Red pine foliar nutrient levels in plots with asymptomatic (A) trees and those in which trees are dying (M) at seven red pine disease sites relative to published critical nutrient levels

\begin{tabular}{|c|c|c|c|c|c|c|c|c|c|c|}
\hline & $\mathrm{Fe}$ & $\mathbf{N}$ & $\mathbf{P}$ & $\mathbf{K}$ & Mg & $\mathrm{Ca}$ & Zn & Mn & B & $\mathrm{Cu}$ \\
\hline Study Site and Plot & $\mathrm{mg} \mathrm{kg}^{-1} \mathrm{a}$ & $\%^{\mathrm{b}}$ & $\%$ & $\%$ & $\%$ & $\%$ & $\mathrm{mg} \mathrm{kg}^{-1}$ & $\mathrm{mg} \mathrm{kg}^{-1}$ & $\mathrm{mg} \mathrm{kg}^{-1}$ & $\mathrm{mg} \mathrm{kg}^{-1}$ \\
\hline Baxter 243b-S-A & $20^{\mathrm{c}}$ & 1.22 & 0.13 & 0.46 & 0.1 & 0.19 & 27 & 186 & $17^{\circ}$ & 2.2 \\
\hline Baxter 243b-N-A & 22 & 1.25 & 0.13 & 0.46 & 0.12 & 0.23 & 31 & 178 & 16 & 2.4 \\
\hline Phelpston $162 \mathrm{e}-\mathrm{A}$ & 21 & 1.33 & 0.13 & 0.43 & 0.14 & 0.34 & 43 & 186 & 15 & 2.7 \\
\hline Baxter 249b-A & 26 & 1.17 & 0.14 & 0.54 & 0.13 & 0.28 & 32 & 64 & 14 & 2.6 \\
\hline Baxter 249b-M & 27 & 1.26 & 0.13 & 0.48 & 0.13 & 0.26 & 31 & 99 & 13 & 2.7 \\
\hline Phelpston 165b-A & $19^{d}$ & 1.22 & 0.12 & 0.4 & 0.13 & 0.23 & 32 & 156 & 20 & 2.5 \\
\hline Phelpston165b-M & 21 & 1.30 & 0.13 & 0.4 & 0.13 & 0.34 & 34 & 157 & 20 & 2.5 \\
\hline Ganaraska $7 \mathrm{~b}-\mathrm{A}$ & 26 & 1.34 & 0.14 & 0.42 & 0.12 & 0.33 & 37 & 126 & 15 & 2.6 \\
\hline Ganaraska 7b-M & 26 & 1.37 & 0.14 & 0.41 & 0.11 & 0.26 & 33 & 113 & 15 & 2.5 \\
\hline Grey-Sauble 89/11-A & 17.6 & 1.31 & 0.12 & 0.4 & 0.17 & 0.28 & 37 & 92 & 20 & 2.7 \\
\hline Grey-Sauble 89/11-M & 18.6 & 1.49 & 0.13 & 0.41 & 0.19 & 0.31 & 41 & 73 & 25 & 2.5 \\
\hline critical level $^{\mathrm{e}}$ & 20 & 1.02 & 0.12 & 0.31 & 0.08 & 0.14 & 23 & 22 & 12 & 2.0 \\
\hline
\end{tabular}

${ }^{a} \mathrm{mg} \mathrm{kg}{ }^{-1}$ needle dry weight

b \% needle dry weight

${ }^{c}$ mean level calculated from bulk samples from two or three limbs in the crown of each of five trees per plot

$\mathrm{d}$ values in bold are below the estimated critical level $(\mathrm{p}=0.05)$

e estimated level of nutrient needed for healthy growth of red pine, as suggested by various studies (e.g., Stone 1953, Mader 1971, Swan 1972; Morrison 1974, Ballard 1986,

Bockheim et al. 1989, Carter 1992, Brockley 2001, Moore et al. 2004). 
Gillespie (1977), it appears that such sites are scattered over much of southern Ontario and can be identified by soil testing prior to plantation establishment.

The Grey-Sauble 89/11 nutrient deficiency site was the most divergent of the study sites, with its soil derived from dolomitic-limestone till (Gillespie and Richards 1954), and was low in $\mathrm{P}$ and high in Mn compared to the other sites. Although the soil P level was significantly lower than at any of the other sites, the foliar $\mathrm{P}$ content of $0.12 \%$ indicates that phosphate fixation by $\mathrm{CaCO}_{3}$, if occurring, was insufficient to cause P deficiency symptoms (Hilal et al. 1973). Although the soil Fe levels in both plots compared favourably with levels found on other sites, the below-critical foliar Fe levels in both plots indicate low uptake.

\section{Black pineleaf scale}

Forest health monitoring records for Ontario contain only one previous report of black pineleaf scale; minor damage in 2003 to a red pine plantation located approximately $20 \mathrm{~km}$ to $25 \mathrm{~km}$ east of the study site (K. Nystrom, Natural Resources Canada, personal communication, 2005). At the black pineleaf scale site, Brookdale $8 \mathrm{a}$, no major differences were found between soil factors of asymptomatic and mortality plots. However, sand content was greater and mycorrhizal colonization was very low in mortality plots. Mortality from black pineleaf scale has been reported in Oregon (ODF 2008), where infestations of natural pine forests and Christmas tree plantations have been associated with drought as well as road dust and insecticide drift that negatively affected the scale's natural enemies (e.g., parasitic wasps; Ferrel 1986). Sustained scale attack often leads to bark beetle attack and subsequent tree death. At the Brookdale 8a site, red turpentine beetles (Dendroctonus valens LeConte) were observed on recently killed trees and trees near death but these beetles were not numerous.

The significantly lower level of mycorrhizal colonization on trees under insect attack has been reported by others. Gehring and Whitham (1991) demonstrated that feeding by the larvae of the pine tip moth (Dioryctria albovitella [Hulst]) reduced ectomycorrhizal colonization of infested pinyon pine (Pinus edulis Engelm.) an average of 33\% relative to resistant trees. Gehring et al. (1997) showed that the pinyon pine needle scale (Matsucoccus acalyptus [Herbert]) had a similar effect on pinyon pine. Gehring and Whitham (1991), Mopper et al. (1991), and Gehring et al. (1997) also described significant variation in the effect of insect herbivory on mycorrhizal colonization of pinyon pine related to genetic variation in susceptibility of individual trees to insect attack. Trees that were resistant to insect attack had significantly higher levels of mycorrhizal colonization than adjacent susceptible trees.

\section{Soil factors}

The most prominent observation in the study was the alkaline reaction of the $\mathrm{C}$ horizon on sites with disease and the acidic reaction on sites without disease. On some sites (e.g., Norfolk County, North 30b, Brookdale 8a), rooting in the unweathered, undisturbed $\mathrm{C}$ horizon was limited or non-existent. Earlier studies have attributed rooting restriction largely to soil bulk density. In one study (Armson and Williams 1960), root elongation of seedlings grown in glass tubes was significantly reduced in compacted neutral non-calcareous and alkaline calcareous sandy soils (bulk density 1.45) versus loose soil (bulk density 1.02). Fayle (1975) and Fayle and Pierpoint (1975) studied red pine rooting in southern Ontario plantations and concluded that a soil bulk density greater than 1.40 hindered root penetration. Faulkner and Malcolm (1972) reported that Scots pine (Pinus sylvestris L.) root extension ceased in British upland heath soils of calcareous origin where bulk density was between 1.40 and 1.67.

In this study, bulk densities exceeding $1.40 \mathrm{~g} \mathrm{ml}^{-1}$ were encountered in the $\mathrm{C}$ horizon on all but one site (i.e., Randwick 1 disease site), including the healthy sites where rooting was deepest. Therefore, limited rooting depth on the disease sites may have been due to nutrient availability, rather than soil density. Root proliferation generally occurs where nutrients are plentiful and is avoided where nutrients are limited (Drew 1975; Robinson 1994, 1996). At all disease sites (except Gurd Pr18), where rooting occurred almost exclusively in the $\mathrm{A}$ and $\mathrm{B}$ horizons, $\mathrm{CaCO}_{3}$ levels were high and extractable $\mathrm{P}$ levels very low in the $\mathrm{C}$ horizon, whereas greater $\mathrm{P}$ availability in the $\mathrm{C}$ horizon on the healthy sites may have encouraged continued root extension. Armson (1968) associated cessation of root extension at the interface between soil regions with and without free $\mathrm{CaCO}_{3}$, but did not relate it to any particular nutrient. Rather, he referred to the upper limit of free $\mathrm{CaCO}_{3}$ as defining the limit of "rootable soil".

\section{Recommendations}

Several factors should be considered when establishing a red pine plantation, including site selection, planting stock choice, and the timing and method of planting. Red pine grows best in dry areas on sandy, coarse, well-drained loam soil (OMNR 1999). Results of this study indicate that soil alkalinity may be an essential factor to consider, as it affects rotation age, product size, succession, and longevity of the plantation. For example, trees on a site with alkaline A, B, and C soil horizons may grow fairly well for 30 to 40 years but then decline and die from nutrient deficiency. Such a site may be suitable for growing a pulp crop or smaller-dimension logs that can be used for the manufacture of posts or landscape timbers. If this site information is obtained prior to plantation establishment, however, the manager may choose to plant another species that is more tolerant of alkaline soil conditions.

Our observations suggest that healthy red pine growth may be sustained longer and may yield larger sawlogs and/or smaller utility pole stock on sites with acidic A and B horizons, especially if these horizons are relatively deep. If the goal is to grow large sawlogs and utility pole stock, a site with acidic $\mathrm{A}, \mathrm{B}$, and $\mathrm{C}$ soil horizons is best. Therefore, although a pre-establishment soil $\mathrm{pH}$ assessment is optimum, assessment of already established plantations can help resource managers to formulate realistic expectations for plantation development and timber product yields.

\section{Acknowledgements}

We wish to acknowledge the invaluable assistance and support of Bob Hutchison and Graeme Davis of the County of Simcoe and Richard Wilson of the Ontario Ministry of Natural Resources' (OMNR) Forest Health and Silviculture Section. We also express our gratitude to the many foresters, technicians, and students without whose assistance the project could not have been completed. This paper is based on 
work included in the $\mathrm{PhD}$ dissertation submitted to the University of Guelph by J.A. McLaughlin. We acknowledge the financial support of the OMNR, the County of Simcoe, and the Norfolk Land Stewardship Council, and the in-kind contributions of Norfolk County, Dufferin County, York Region, Ganaraska Region Conservation Authority, Miller Lumber Ltd., and Tembec Forest Products. Special thanks to Trudy Vaittinen and Lisa Buse of the Ontario Forest Research Institute's Technology Transfer Unit for help with graphics and editing.

\section{References}

Agriculture Canada Expert Committee on Soil Survey. 1987. The Canadian system of soil classification. 2nd ed. Agric. Can. Publ. 1646. $164 \mathrm{p}$.

Armson, K.A. 1968. Soils, roots, and foresters. In C.T. Youngberg and C.B. Davey (eds.). Tree Growth and Forest Soils. Proceedings of the Third North American Forest Soils Conference, Aug. 1968. pp. 513-522. N.C. State Univ. Raleigh, NC. 527 p.

Armson, K.A. and J.R.M. Williams. 1960. The root development of red pine (Pinus resinosa Ait.) seedlings in relation to various soil conditions. For. Chron. 36(1): 14-17.

Ballard, T.M. 1986. Evaluating forest stand nutrient status. Land Management Rep. No. 20. BC Min. For., Victoria, BC. 60 p.

Bendz-Hellgren, M. and J. Stenlid. 1997. Decreased volume growth of Picea abies in response to Heterobasidion annosum infection. Can. J. For. Res. 27(10): 1519-1524.

Bockheim, J.G., J.E Leide and L.E. Frelich. 1989. Red pine growth and chemical composition of foliage and forest floors across a precipitation-chemistry gradient in Wisconsin. Can. J. For. Res. 19(12): 1543-1549.

Bouyoucos, G.J. 1962. Hydrometer method improved for making particle size analyses of soils. Agron. J. 54(5): 464-465.

Brockley, R. 2001. Foliar sampling guidelines and nutrient interpretative criteria for lodgepole pine. BC Min. For., Victoria, BC. Extension Note 52.8 p.

Brown, W.G.E. and D.S. Lacate. 1961. Rooting habits of white and red pine. Can. Dept. For., For. Res. Br., Ottawa. Tech. Note No. 108. 16 p.

Bryant, J.P., F.S. Chapin, P.B. Reichardt and J.P. Clausen. 1987. Response of winter chemical defence in Alaska paper birch and green alder to manipulation of plant carbon/nutrient balance. Oecologia 72(4): 510-514.

Carter, R.E. 1992. Diagnosis and interpretation of forest stand nutrient status. In H.N. Chappell, G.F. Weetman and R.E. Miller (eds.) Forest Fertilization Sustaining and Improving Nutrition and Growth of Western Forests., U. Washington, Seattle, WA. Coll. For. Resour. Contrib. 73 .

Cook, E., K. Briffa, S. Shiyatov and V. Mazepa. 1989. Section 3.3. Tree-ring Standardization and Growth-trend Estimation. In E. Cook and L. Kairiukstis (eds.) Methods of Dendrochronology. pp.104-123. Kluwer Academic Publishers, Dordrecht, NL. 394 p. Czerwinski, E.J., J.H. Meating, P.M. Bolan and M.W. Francis. 1998. The incidence and impacts of Annosum Root Rot, Heterobasidion annosum, in southern Ontario. BioForest Technologies Inc., Report prepared for Ontario Ministry of Natural Resources. 33 p. + append. Dawson, T.E. 1996. Determining water use by trees and forests from isotopic, energy balance and transpiration analyses: the roles of tree size and hydraulic lift. Tree Physiol. 16(1-2): 263-272.

Dils, R.E. and M.W. Day. 1952. The effect of precipitation and temperature upon the radial growth of red pine. Am. Midland Nat. 48(3): 730-734.

Drew, M.C. 1975. Comparison of the effects of a localized supply of phosphate, nitrate, ammonium and potassium on the growth of the seminal root system, and the shoot, of barley. New Phytol. 75(3): 479-490
Duchesne, L., R. Ouimet and C. Morneau. 2003. Assessment of sugar maple health based on basal area growth pattern. Can. J. For. Res. 33(11): 2074-2080.

Ellis, R.C. and R.D. Whitney. 1975. Preliminary observations on mortality of red pine on a calcareous soil in southern Ontario. Dept. Environ., Can. For. Serv., Bi-Monthly Res. Notes 31(4): 27-29.

Entry, J.A. and K. Cromack, Jr. 1988. Phenolic compounds inhibit Armillaria growth in vitro. In D.J. Morrison (ed.). Proceedings of the Seventh International Conference on Root and Butt Rots. pp. 632-640. Pac. For. Cent., Victoria, BC. 680 p.

Entry, J.A., K. Cromack, Jr., R.G. Kelsey and N.E. Martin. 1991. Response of Douglas-fir to infection by Armillaria ostoyae after thinning or thinning plus fertilization. Phytopathology 81(6): 682-689.

Faulkner, M.E. and D.C. Malcolm 1972. Soil physical factors affecting root morphology and stability of Scots pine on upland heaths. Forestry 45(1): 23-36.

Fayle, D.C.F. 1975. Extension and longitudinal growth during the development of red pine root systems. Can. J. For. Res. 5(1): 109-121.

Fayle, D.C.F. and G. Pierpoint. 1975. Evolvement of root and shoot systems of red pine on soils of different moisture availability. In B. Bernier and C.H. Winget (eds.). Forest Soils and Forest Land Management. Proceedings of the Fourth North American Forest Soils Conference, August 1973. pp. 11-25. Laval University, QC.

Ferrel, G. 1986. Black pineleaf scale. USDA For. Serv., Forest Pest Leaflet 91.5 p.

Froelich, R.C, E.B. Cowling, L.V. Collicott and T.R. Dell. 1977. Fomes annosus reduces height and diameter growth of planted slash pine. For. Sci. 23(3): 299-306.

Gehring, C.A. and T.G. Whitham. 1991. Herbivore-driven mycorrhizal mutualism in insect-susceptible pinyon pine. Nature 353: 556-557.

Gehring, C.A., N.S. Cobb and T.G. Whitham. 1997. Three-way interactions among ectomycorrhizal mutualists, scale insects, and resistant and susceptible pinyon pines. Am. Nat. 149(5): 824-841.

Gillespie, J.E. 1977. Soil capability studies for pine in Ontario. A report prepared for the Ontario Ministry of Natural Resources. Univ. of Guelph. 7 p. + append.

Gillespie, J.E. and N.R. Richards. 1954. Soil survey of Grey County. Report No. 17 of the Ontario Soil Survey. Experimental Farms Serv., Can. Dept. Agric. and OAC. 79 p.

Hilal, M.H., F. Anter and A.H. El-Damaty. 1973. A chemical and biological approach towards the definition of calcareous soils. I. Movement and retention of $\mathrm{P}^{32}$ in soil as affected by percentage and particle size of calcium carbonate fraction. Plant Soil 39(3): 469-478. Hosie, R.C. 1979. Native Trees of Canada. $8^{\text {th }}$ ed. Fitzhenry \& Whiteside Ltd. Markham, ON. 380 p.

Jorgensen, E. 1956. Fomes annosus (Fr.) Cke. root rot in Ontario. For. Chron. 32(1): 87-88.

Kalra, Y.P. and D.G. Maynard. 1991. Methods manual for forest soil and plant analysis. For. Can., Northwest Region, North. For. Cent., Edmonton, AB. Info. Rep. NOR-X-319.

Kirk, T.K. 1981. Toward elucidating the mechanism of action of the lignolytic system in basidiomycetes. In A. Hollaender (ed.). Trends in Biology of Fermentation for Fuels and Chemicals. pp. 131-148. Plenum Press, New York.

Lavender, D.P. 1970. Foliar analysis and how it is used. A review. Oregon State Univ., School of Forestry, For. Res. Lab., Res. Note 52.8 p. MacIvor, D.C., F. Raymond and H. Dallans. 1985. TRIM sampling design manual. Ont. Min. Nat. Resour., Forest Resources Group, Toronto, ON. 200 p.

Mader, D.L. 1971. Growth and foliar nutrients in direct seeded red pine in relation to micro-site. For. Chron. 47(6): 341-344.

Mallet, K.I. and W.J.A. Volney. 1999. The effect of Armillaria root disease on lodgepole pine tree growth. Can. J. For. Res. 29(2): $252-259$. 
McLaughlin, J.A. 2001a. Impact of Armillaria root disease on succession in red pine plantations in southern Ontario. For. Chron. 77(3): 519-524.

McLaughlin, J.A. 2001b. Distribution, hosts and site relationships of Armillaria spp. in central and southern Ontario. Can. J. For. Res. 31(9): 1481-1490.

McLaughlin, J.A. 2008. Abiotic and biotic factors associated with pocket mortality of red pine (Pinus resinosa Ait.) in southern Ontario. Ph.D. Thesis, Dept. Environmental Biology, Univ. of Guelph, Guelph, ON. 356 p.

McLaughlin, J.A. and T. Hsiang. 2010. Identification protocol for six Armillaria species from northeastern North America. Can. J. For. Res. 40(3): 536-548.

Moore, J.A., P.G. Mika, T.M. Shaw and M.I. Garrison-Johnston. 2004. Foliar nutrient characteristics of four conifer species in the interior northwest United States. West. J. Appl. For. 19(1): 13-24.

Mopper, S., J.B. Mitton, T.G. Whitham, N.S. Cobb and K.M. Christensen. 1991. Genetic differentiation and heterozygosity in pinyon pine associated with resistance to herbivory and environmental stress. Evolution 45(4): 989-999.

Morrison, I.K. 1974. Mineral nutrition of conifers with special reference to nutritional status interpretation: A review of literature. Can. Dept. Environ., Can. For. Serv., Victoria, BC. Publ. No. 1343. 74 p. Mosseler, A., K.N. Egger and G.A. Hughes. 1992. Low levels of genetic diversity in red pine confirmed by random amplified polymorphic DNA markers. Can. J. For. Res. 22(9): 1332-1337.

[OMNR] Ontario Ministry of Natural Resources. 1999. Managing red pine plantations. Land Resource Centre, Manotick, ON. Extension Note AGDEX 325. 6 p. Available at http://www.lrconline.com/ Extension_Notes_English/pdf/mngng_rd_pn.pdf [Accessed 14 May 2010].

[OMNR and NRCan] Ontario Ministry of Natural Resources and Natural Resources Canada. 2007. Forest health conditions in Ontario, 2006. T. Scarr, A. Hopkin and J. Pollard (eds.). 81 p. Available at (http://www.mnr.gov.on.ca/STEL02_197109.pdf [Accessed 26 February 2010].

[ODF] Oregon Department of Forestry. 2008. Forest health. Available at http://www.odf.state.or.us/DIVISIONS/management/state forests/sfplan/eorfmp95-final/3_2_half.pdf [Accessed 27 April 2010].

Palo, R.T., K.E. Sunnerheim and O. Theander. 1985. Seasonal variation in phenols, crude protein and cell wall content in birch (Betula pendula Roth.) in relation to ruminant digestibility. Oecologia 65(2): 314-318.
Raffle, V.I. and T. Hsiang. 1995. Intersterility groups of Heterobasidion annosum in Canada. Phytopathology 85(10): 1141.

Richards, N.A., R.R. Morrow and E.L. Stone. 1962. Influence of soil and site on red pine plantations in New York. 1. Stand development and site index curves. Cornell Univ., Agric. Exp. Sta., Ithaca, NY. New York State Coll. Agric. Bulletin 977. 24 p.

Richter, D. and J. Bruhn. 1993. Mycorrhizal fungus colonization of Pinus resinosa Ait. transplanted on northern hardwood clearcuts. Soil Biol. Biochem. 25(3): 355-369.

Rishbeth, J. 1972. The production of rhizomorphs by Armillaria mellea from stumps. Eur. J. For. Pathol. 2(4): 193-205.

Robinson, D. 1994. Tansley review no. 73: The responses of plants to non-uniform supplies of nutrients. New Phytol. 127(4): 635-674.

Robinson, D. 1996. Resource capture by localized root proliferation: Why do plants bother? Ann. Bot. 77(2): 179-185.

Rosso, P. and E. Hansen. 1998. Tree vigour and the susceptibility of Douglas fir to Armillaria root disease. Eur. J. For. Pathol. 28(1): 43-52.

Rudolf, P.O. 1990. Red pine (Pinus resinosa Ait.). In R.M. Burns and B.H. Honkala (tech. coords.). Silvics of North America: 1. Conifers. USDA For. Serv., Washington, DC. Agric. Handb. 654. 877 p. Available at http://www.na.fs.fed.us/spfo/pubs/silvics_manual/Volume_1/pinus/resinosa.htm [Accessed 27 April 2010].

Schoeneweiss, D.F. 1975. Predisposition, stress and plant disease. Ann. Rev. Phytopathology 13: 193-211.

Stone, E.L. 1953. Magnesium deficiency of some northeastern pines. Soil Sci. Soc. Am. J. 17(3): 297-300.

Stone, E.L., R.R. Morrow and D.S. Welch. 1954. A malady of red pine on poorly drained sites. J. For. 52(2): 104-114.

Swan, H.S.D. 1972. Foliar nutrient concentrations in red pine as indicators of tree nutrient status and fertilizer requirement. Pulp Pap. Res. Inst. Can., Woodlands Rep. 19 p.

Wargo, P.M. 1980. Interaction of ethanol, glucose, phenolics, and isolates of Armillaria mellea. (Abstr.) Phytopathology 70(6): 470.

Weltzin, J.F. and G.R. McPherson. 1997. Spatial and temporal soil moisture resource partitioning by trees and grasses in a temperate savanna, Arizona, USA. Oecologia 112(2): 156-164.

Whitney, R.D. 1988. Armillaria root rot damage in softwood plantations in Ontario. For. Chron. 64(4): 345-351.

Worrall, J.J. and T.C. Harrington. 1992. Heterbasidion.. In L.L. Singleton, J.D. Mihail and C.M. Rush (eds.). Methods for Research on Soilborne Phytopathogenic Fungi. pp. 86-90. APS Press, St. Paul, MN. 